\title{
Mapping of GIS-Land Use Suitability in the Rural-Urban Continuum between Ar Riyadh and Al Kharj Cities, KSA Based on the Integrating GIS Multi Criteria Decision Analysis and Analytic Hierarchy Process
}

\author{
Ashraf Abd El Karim ${ }^{1} * * \mathbb{D}$, Haya M. Alogayell ${ }^{2}$, Ibtesam I. Alkadi ${ }^{2}$ and Ismail Youssef ${ }^{3}$ \\ 1 Research Center, Ministry of Housing, Riyadh, Riyadh 84428, Saudi Arabia \\ 2 Geography Department, College of Arts, Princess Nourah bint Abdulrahman University, \\ Riyadh 84428, Saudi Arabia; hmalogayell@pnu.edu.sa (H.M.A.); Ebtesam.K@gmail.Com (I.I.A.) \\ 3 Department of Geography, Faculty of Art, Monofiya University, Shbeen El Koom 32511, Egypt; \\ youssefegyptgeo@gmail.com \\ * Correspondence: dr.ashrafgis2020@gmail.com
}

Received: 2 September 2020; Accepted: 23 September 2020; Published: 26 September 2020

\begin{abstract}
The management of land use in big cities and capitals and the surrounding adjacent urban aggregates is still of major importance in the field of urban development, especially in cities with populations of millions and various types of land uses and economic activities. The rural-urban continuum between the cities of Ar Riyadh and $\mathrm{Al}$ Kharj suffers from an unclear general land use trend, due to urban expansion at the expense of the agriculture lands, the imbalance of the population compound, the deterioration of the urban fabric, lack and poor distribution of services, and the dominance of industrial land use at the expense of other uses. These factors have led to an increase in environmental changes and loss of the environmental and ecological characteristics of this area between Ar Riyadh and Al Kharj. The present study aims at evaluating the land use suitability for urban development in the rural-urban continuum between Ar Riyadh and Al Kharj cities. This is achieved by using the GIS-based Multi Criteria decision Analysis (GIS-MCDA) on twelve various economic, environmental, urban, and law criteria. The weights of criteria were determined using the Analytic Hierarchy Process (AHP) method. The results of the spatial suitability map of the land use for sustainable urban development revealed that there are five categories of spatial suitability ranging in suitability from $32 \%$ to $86 \%$. The recommended areas for sustainable urban development are those with a spatial suitability upwards of $70 \%$ in the rural-urban continuum corridor between Ar Riyadh and $\mathrm{Al}$ Kharj cities. The sustainable development in this corridor can be achieved by executing high priority projects that ensure and support the urban sustainable development plan through establishing four local urban development centers and upgrading four current villages to rural communities, aiming at strengthening the functional bonds between the rural communities and the local urban development centers. These projects will limit the sustainable urban development to specific areas without allowing random expansion, avoiding the urban conjugation of the two Ar Riyadh and $\mathrm{Al}$ Kharj cities through the connecting area between them.
\end{abstract}

Keywords: the rural-urban continuum; spatial suitability; MCDA; AHP; land use management; sustainable urban development 


\section{Introduction}

There is increasing worldwide interest in the study of cities' surrounding areas [1-4]. It can't be denied that these areas show effects relating to both the social environmental activities and the infrastructure $[2,3,5]$. The rapid civilization yields many problems that affect the environmental sustainability at all levels $[1,3,6]$; these problems are widely abundant in the areas surrounding cities and urban communities, as these areas became favorable for resettlement to most people settling in cities for practicing their economical and commercial activities [7-9], due to the relatively low rent and the availability of agricultural lands near by the work centers in the city [10-14].

The rural-urban continuum describes the peripheral areas of cities absorbing the excess flow of population and commercial activities. It is regarded as a transitional stage between the urban and semi-urban areas, showing the characteristics of both the urban and rural environments. These areas are characterized by continuous changes in the pattern of land uses, and the way the people live and the urban extension they constitute. These areas are zones of transitional demographic and social characteristics, having various types of land uses with a predominance of agriculture land use [7,15-18].

Due to the strategic locations of the rural-urban continuums and their multifunctional capabilities, all types of land use in these areas are continuously affected by their location. Consequently, it is a must to evaluate the land suitability for environmental urban development in these areas to cease the undesired random urban expansion and protect the characteristics of these areas (areas surrounding cities or cities' peripheral areas) [19].

Land suitability evaluation is the prediction of the suitability of a land to a specific type of land use in an area, this provides a logic basic for land use planning [20] especially in developing countries. One of the key issues in land use planning is determining the suitable locations for urban development in cities' peripheral areas. Land use decisions for sustainable urban development requires considering various physical, environmental, demographic, natural, economic, planning, social, and managerial factors. Combining these factors in the decision making process is not always an easy task, as these decisions will be made for evaluating the suitability of land to a specific purpose [21]. This provides a larger overview for developing and planning the lands of these areas and supports the use of resources according to scientific logical basics [22-28]. Scientists have done many studies on evaluating land suitability; in the 1960s, land suitability evaluation was the main basis for urban planning [29], and since the 1970s GIS techniques have encouraged the development of land suitability evaluation [24,25,30-35]. Catching up with new advances in the technologies of data collection and processing, the land suitability technique is applied in various fields including crop suitability evaluation [36-40], landscape planning and hazards [41,42], water management and planning [43-45], evaluation of the environmental impacts [46,47], evaluation of land uses [48-50], and sustainable urban development [51-54].

Suitability analysis consists of the processes and procedures used for proving the suitability of a system based on the needs of the beneficiaries. The land suitability evaluation involves defining the suitable locations for development through determining the suitability index of a specific area $[55,56]$. GIS techniques are powerful tools for monitoring urban and environmental changes and their impacts on the ecological system [57]. Analyzing the land suitability using GIS is a process for determining the optimal locations for development, taking into account the environmental sustainability [58]. Other tools are integrated with the GIS techniques for determining the importance and weights of the criteria used in the analytic process. The integration of the GIS and Multi Criteria Decision Analysis (MCDA) techniques is regarded as a powerful approach for evaluating land suitability [59]. Planning for sustainability enhances the suitability analysis, which is a complicated process as it depends on different factors and criteria to be taken into consideration during the suitability evaluation analysis [60].

MCDA is used for analyzing the suitability of lands to urban growth and treating the decision-making problems using multiple criteria [25,61,62]. The aim of MCDA is studying the probabilities suggested based on multi criteria and multi objectives [63]. The Analytic Hierarchy 
Process (AHP) method that was developed by Saaty [64] is one of the most important methods for analyzing land suitability and providing the decision makers and planners with the statistical analysis data before they make their final decision regarding the future changes in land uses [65-68]. Integration of AHP and GIS was done to determine the importance of the used criteria and to calculate their weights according to importance, with regard to experts' opinions [69-71].

The study problem appears in the unclear general trend for land uses: the urban strategy of KSA recommends the corridor to have industrial, commercial, and agriculture activities to support the economy in the central area of the kingdom, while, the planning of Al Kharj city suggests that this area should be an agricultural recreational corridor, having no industrial constructions to avoid urban concentration and the conjugation of the urban masses of Ar Riyadh and Al Kharj.

This is in addition to the rapid changes in the land use map of the continuum and the growing urban expansion at the expense of the agriculture lands. Agricultural lands lost about $60 \mathrm{~km}^{2}$ from their total area during the past thirty years, from 1988-2019, with an annual average decrease of $2 \mathrm{~km}^{2}$. This decrease favored the indiscriminate industrial and urban invasion, where the industrial spaces increased with a growth rate of $4 \%$ and the urban areas increased similarly. This led to an the imbalance of the population compound, the deterioration of the urban fabric, lack and poor distribution of services, dominance of the industrial land use at the expense of other uses, an increase in environmental changes, and loss of the environmental and ecological characteristics of this area between Ar Riyadh and Al Kharj.

The regional development of the Ar Riyadh-Al Kharj rural-urban continuum is becoming increasingly unstable, so it is a major issue for the planners and policy makers to achieve balance between economic development activities and the environmental safety of this area, through evaluating land suitability for development.

The present study aims at evaluating the land suitability for sustainable urban development of the rural-urban continuum between Ar Riyadh and Al Kharj cities to guarantee the sustainability of resources and achieve sustainable environmental, urban, and economic development in this area, in accordance with the KSA vision 2030. This is achieved through using the GIS-based Multi Criteria Decision Analysis (GIS-MCDA) on twelve different economic, environmental, urban, and law criteria. The weights of criteria were determined using the AHP method.

\section{Area of Study}

The rural-urban continuum between the cities of Ar Riyadh and Al Kharj lies on the Ar Riyadh-Al Kharj highway, extending about $45 \mathrm{~km}$ in length with an average width of about $4.5 \mathrm{~km}$ on both sides of the road. It extends from the end of the industrial south of Ar Riyadh to the beginning of (exit number (7)) the north of $\mathrm{Al}$ Kharj. It is located between latitudes $24^{\circ} 13^{\prime} 58.31^{\prime \prime} \mathrm{N}$ to $24^{\circ} 29^{\prime} 48.57^{\prime \prime} \mathrm{N}$ and longitudes $46^{\circ} 56^{\prime} 29.62^{\prime \prime} \mathrm{E}$ to $47^{\circ} 12^{\prime} 44.44^{\prime \prime} \mathrm{E}$ (Figure 1). 


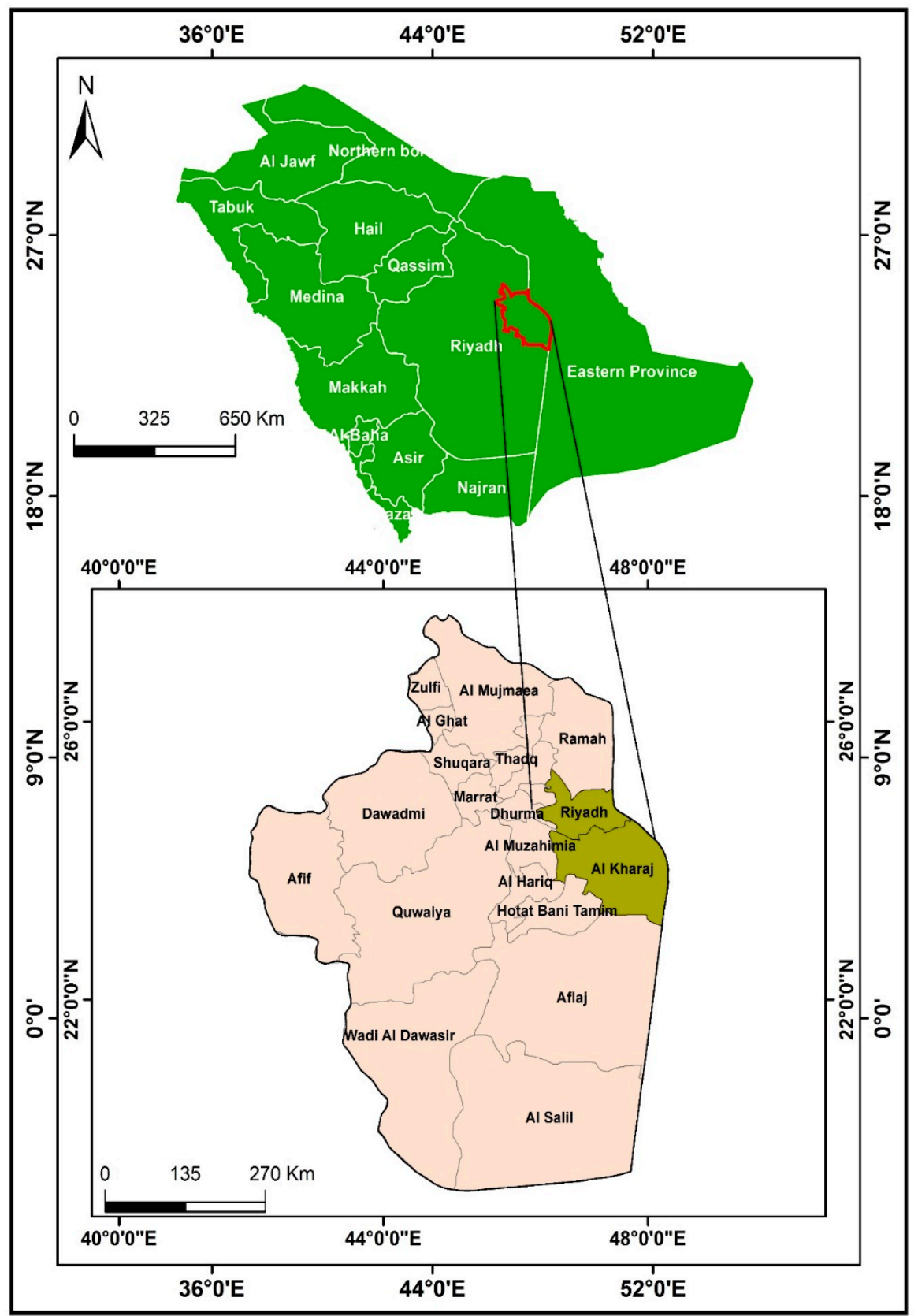

Figure 1. Location of the rural-urban continuum (Ar Riyadh-Al Kharj), KSA, 2019.

The study area comprises seven urban communities listed from south to north as the following: Al Bjadyah, Ar Refaeiyah, Heit Al Janowbeyiah, Al Amajiah, Heit, and Ar Rayyah, with a population of 16,819 inhabitants (after the general survey authority, 2018). The study area is characterized by the presence of various land uses with predominantly industrial land use at a large scale; besides the existence of palm farms and their related industries, there are also many recreational sites including camping areas, open spaces, and rests from analysis. The Landsat-OLI 8 satellite images for 2019 were obtained from the United States Geologic Survey (USGS) website (Figure 2). 


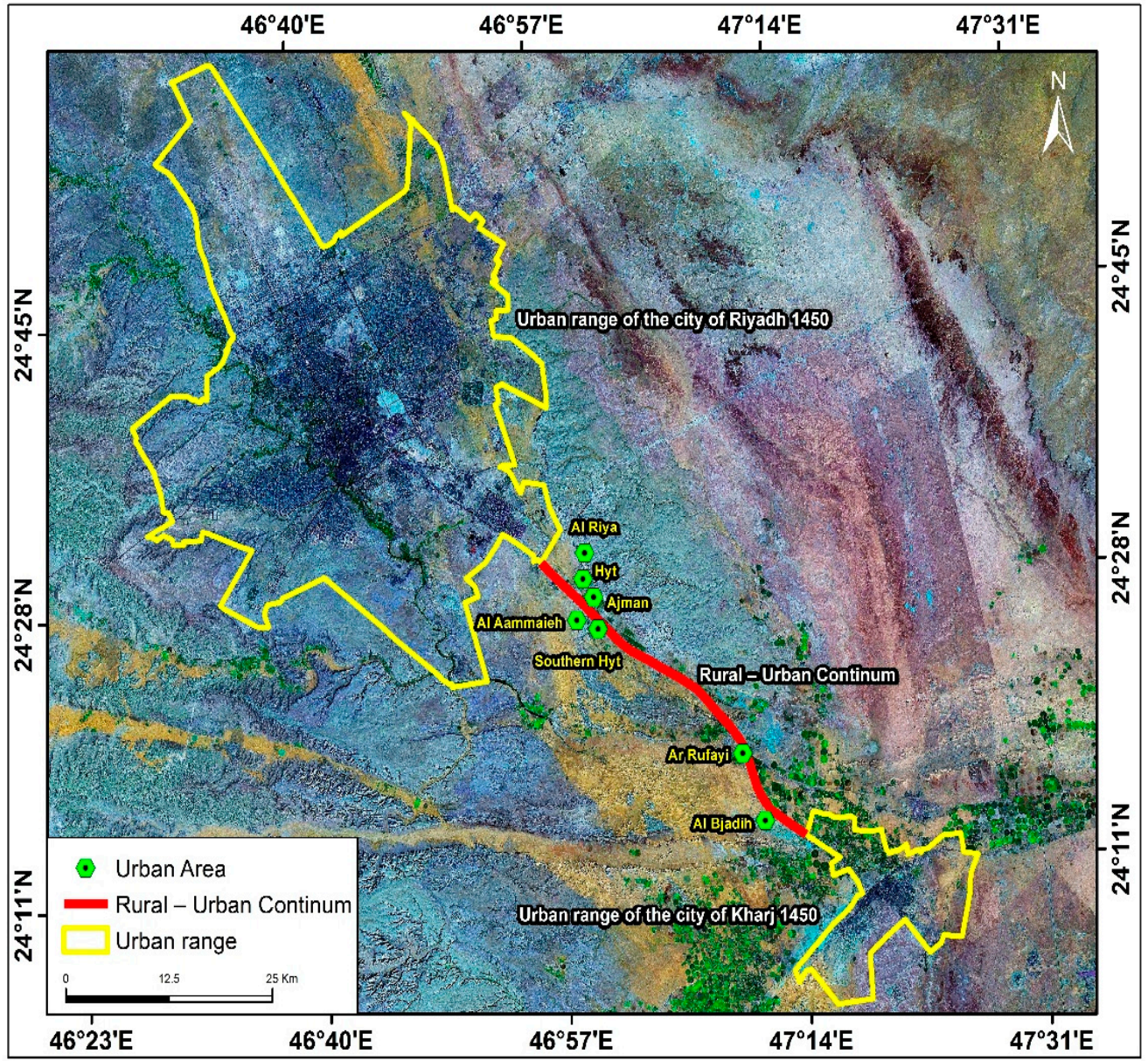

Figure 2. The rural-urban continuum between Ar Riyadh and Al Kharj cities, 2019.

Figures 3 and 4 indicate the most important features of the change in the urban-rural contact area during the period from 1988-2019, in which agricultural lands decreased by about $60 \mathrm{~km}^{2}$ out of a total area of $225 \mathrm{~km}^{2}$ in 1988, which became $162 \mathrm{~km}^{2}$ in 2019 when the annual decrease rate reached about 2 $\mathrm{km}^{2}$. The annual decreasing growth rate was about $1 \%$. Urban areas increased from $36 \mathrm{~km}^{2}$ to $114 \mathrm{~km}^{2}$ with a growth rate of $4 \%$ and an average annual increase of $2.5 \mathrm{~km}^{2}$ during the same period. There was also an invasion and occupation of industrial areas, which increased from $12 \mathrm{~km}^{2}$ to $42 \mathrm{~km}^{2}$ during the same period, with a growth rate of $4 \%$ and an average annual increase of $1 \mathrm{~km}^{2}$. This requires rapid intervention to control industrial and urban expansions at the expense of agricultural land by way of setting a comprehensive vision for sustainable urban development in this vital area. 


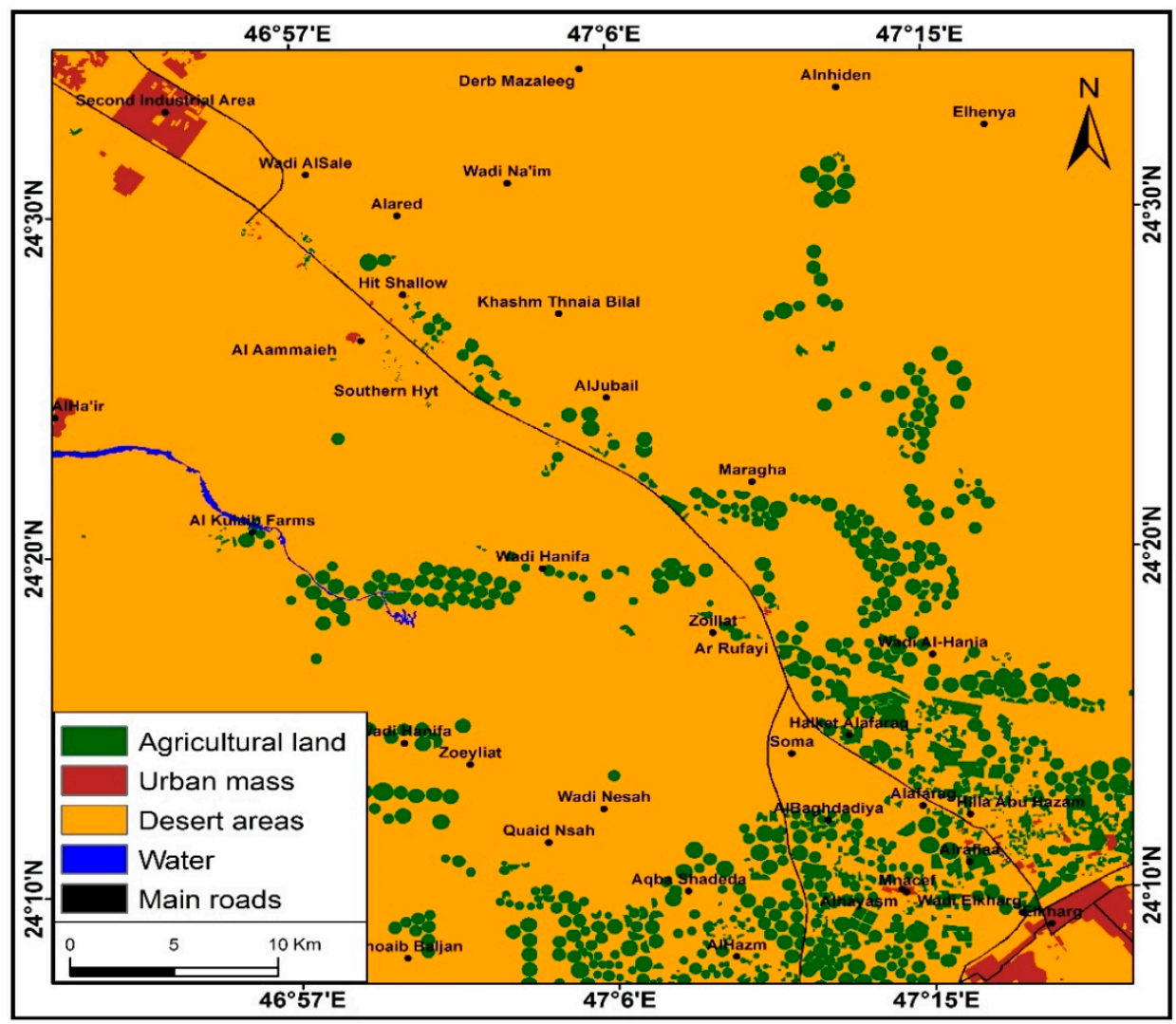

Figure 3. The land use of the rural-urban continuum between Ar Riyadh and Al Kharj cities, 1988.

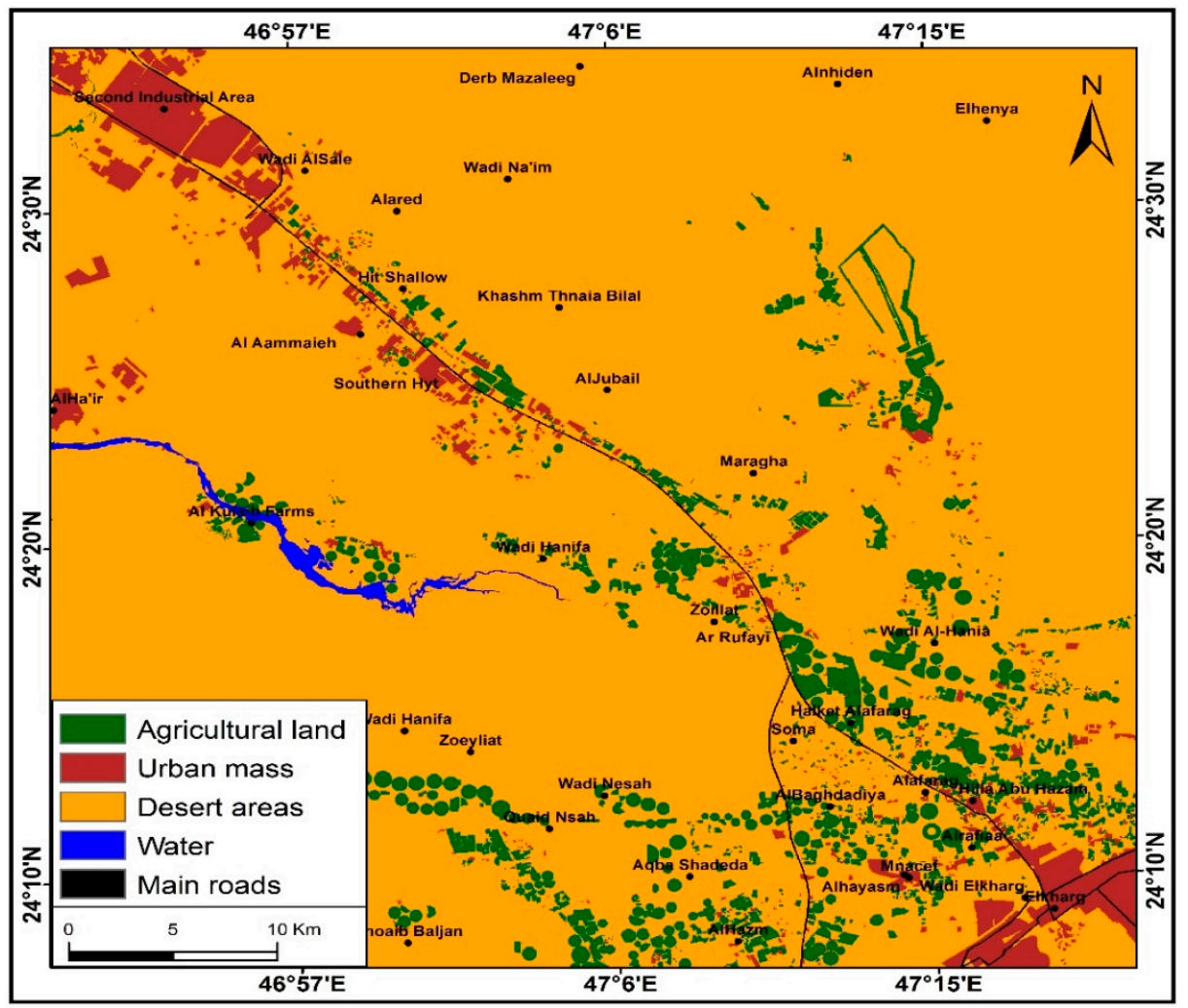

Figure 4. The land use of the rural-urban continuum between Ar Riyadh and Al Kharj cities, 2019. 


\section{Methodology and Data Processing}

The main objective of using the MCDA technique is analyzing many selection probabilities in light of multiple criteria. The MCDA technique allows evaluating and supporting the decision-making process in the urban regional planning processes [72]. Stages the study goes through to obtain the final spatial suitability map are illustrated in Figure 5.

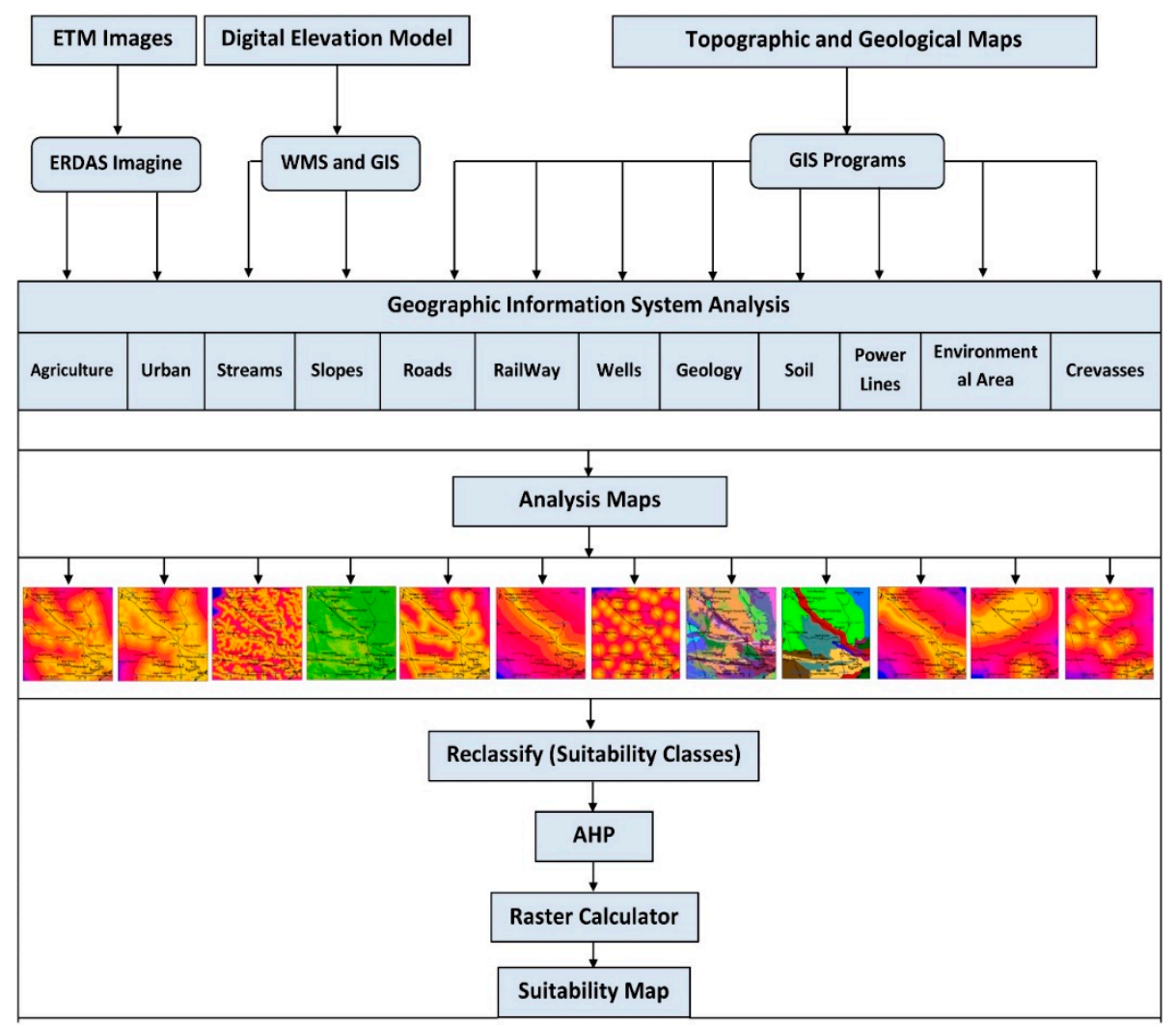

Figure 5. Evaluation of land use suitability for sustainable urban development in the rural-urban continuum (Ar Riyadh-Al Kharj) using the Multi Criteria Decision Analysis (MCDA) technique.

\subsection{The Data Input for MCDA}

To conduct MCDA analysis in the rural-urban continuum between Ar Riyadh and Al Kharj Cities, the necessary data was obtained from several different sources with standardization of measurements and projections, so that data integrated within the geographic information systems and data from different sources were collected to cover all the information about the twelve criteria; five topographic maps with scale 1:50,000, and a geologic map (GM-121 C) of Ar Riyadh with scale 1:250,000 were obtained from the General Authority for Geologic Survey. Digital Elevation Model (DEM) data with a resolution of $12 \mathrm{~m}$ was obtained from the (Vertex) website of NASA. Landsat-OLI 8 satellite images for 2019 were obtained from the United States Geologic Survey (USGS) website for monitoring and delineating the agriculture areas, urban areas, and other features that might be of interest to the study. The Atlas maps of the regional planning of Ar Riyadh were also implemented in the study and were obtained from the "Royal commission for Riyadh city", and the maps of the regional planning of $\mathrm{Al}$ Kharj were obtained from the Ministry of Municipal and Rural Affairs of KSA. Table 1 shows the input data, types, spatial accuracy and sources. 
Table 1. The input data, spatial accuracy, and sources used in study.

\begin{tabular}{|c|c|c|c|}
\hline $\mathbf{M}$ & Input Data & Scale and Spatial Accuracy & Source \\
\hline 1 & Geologic Formation & scale $1: 250,000$ & $\begin{array}{l}\text { General Authority for } \\
\text { Geologic Survey }\end{array}$ \\
\hline 2 & Soil & scale $1: 250,000$ & $\begin{array}{l}\text { Ministry of environment } \\
\text { water \& Agriculture }\end{array}$ \\
\hline 3 & Streams/Valleys & DEM $12 \mathrm{~m}$ & (Vertex) website of NASA \\
\hline 4 & Slopes & DEM $12 \mathrm{~m}$ & (Vertex) website of NASA \\
\hline 5 & Agriculture Areas & satellite image Landsat 8/OLI & $\begin{array}{l}\text { United States Geologic Survey } \\
\text { (USGS) website }\end{array}$ \\
\hline 6 & Urban Areas & satellite image Landsat 8/OLI & $\begin{array}{l}\text { United States Geologic Survey } \\
\text { (USGS) website }\end{array}$ \\
\hline 7 & Road Networks & satellite image Landsat 8/OLI & $\begin{array}{l}\text { United States Geologic Survey } \\
\text { (USGS) website }\end{array}$ \\
\hline 8 & Railways & $\begin{array}{l}\text { Regional Plan atlas for } \\
\text { Riyadh region }\end{array}$ & $\begin{array}{l}\text { Royal commission for } \\
\text { Riyadh city-2019 }\end{array}$ \\
\hline 9 & Wells & $\begin{array}{l}\text { topographic maps scale } \\
\text { 1:50,000-Regional Plan atlas } \\
\text { for Riyadh region }\end{array}$ & $\begin{array}{c}\text { General Authority for Geologic } \\
\text { Survey—Royal commission for } \\
\text { Riyadh city-2019 }\end{array}$ \\
\hline 10 & Power Lines & $\begin{array}{l}\text { topographic maps } \\
\text { scale } 1: 50,000\end{array}$ & $\begin{array}{l}\text { General Authority for } \\
\text { Geologic Survey }\end{array}$ \\
\hline 11 & Crevasses/Faults & $\begin{array}{l}\text { topographic maps } \\
\text { scale } 1: 50,000\end{array}$ & $\begin{array}{l}\text { General Authority for } \\
\text { Geologic Survey }\end{array}$ \\
\hline 12 & Environmental Areas & $\begin{array}{l}\text { topographic maps } \\
\text { scale } 1: 50,000\end{array}$ & $\begin{array}{l}\text { General Authority for } \\
\text { Geologic Survey }\end{array}$ \\
\hline
\end{tabular}

\subsection{Criteria Definition}

The initial stage of MCDA is concerned with combining data for several different criteria for decision-making purposes [73]. Based on the current local and international literature and personal interviews [74], the criteria that were found to be influencing the construction of new urban areas in the rural-urban continuum area between Ar Riyadh and Al Kharj cities were determined. Twelve criteria were determined and their weights were defined using the AHP method, these criteria are as follows: "Slopes" (S), “Streams/Valleys" (V), “Urban Areas" (U), "Road Networks" (R), "Railways" (RW), "Agriculture Areas" (A), "Soil Type" (SO), “Geologic Formation" (G), "Crevasses/Faults" (C), "Wells" (W), "Environmental Areas" (E), and "Power Lines" (P).

\subsection{Reclassification of Data}

In this stage, the comparison process was carried out by reclassifying the values of the parameters by replacing the values of the cells of the input layers with values compatible with the analysis procedures, then determining the suitability categories and reclassifying the distance map for each parameter according to the degree of suitability of the ranges. Ten categories were defined for each distance map for all the parameters/criteria; these categories were classified by values from 1 to 10 values, with the distance category closest to the parameter (criteria or facility) being assigned the highest value (10) and that with the longest distance to the parameter being given the lowest value (1). The reclassification process was carried out in Arc GIS software, where the "Spatial Analyst" group is selected, then the "Reclass" group, and finally "Reclassify", as show in Table 2. Figures 6-8 show the distance ranges for the different criteria affecting the rural-urban continuum between the cities of $\mathrm{Ar}$ Riyadh and Al Kharj. 
Table 2. Category classification and suitability for the different criteria affecting the rural-urban continuum between Ar Riyadh and Al Kharj.

\begin{tabular}{|c|c|c|c|}
\hline Parameter & Categories & Suitability & Suitability Value \\
\hline \multirow{2}{*}{ Slopes } & \multirow{2}{*}{$(1-10)$} & less than 2 degrees (higher suitability) & 10 \\
\hline & & more than 35 degrees (low suitability) & 1 \\
\hline \multirow{2}{*}{ Streams/Valleys } & \multirow{2}{*}{$(1-10)$} & less than 200 m (low suitability) & 1 \\
\hline & & more than $3.5 \mathrm{~km}$ (higher suitability) & 10 \\
\hline \multirow{2}{*}{ Urban Areas } & \multirow{2}{*}{$(1-10)$} & less than $1 \mathrm{~km}$ (higher suitability) & 10 \\
\hline & & more than $17 \mathrm{~km}$ (low suitability) & 1 \\
\hline \multirow{2}{*}{ Road Networks } & \multirow{2}{*}{$(1-10)$} & less than $1 \mathrm{~km}$ (higher suitability) & 10 \\
\hline & & more than $14 \mathrm{~km}$ (low suitability) & 1 \\
\hline \multirow{2}{*}{ Railways } & \multirow{2}{*}{$(1-10)$} & less than $1 \mathrm{~km}$ (higher suitability) & 10 \\
\hline & & more than $35 \mathrm{~km}$ (low suitability) & 1 \\
\hline \multirow{2}{*}{ Agriculture Areas } & \multirow{2}{*}{$(1-10)$} & less than 200 m (low suitability) & 1 \\
\hline & & more than $15 \mathrm{~km}$ (higher suitability) & 10 \\
\hline \multirow{3}{*}{ Soil Type } & \multirow{3}{*}{$(1-10)$} & calcic orthider (low suitability) & \\
\hline & & torry samantas + rock fragments and & 1 \\
\hline & & notches (higher suitability) & 10 \\
\hline \multirow{2}{*}{ Geologic Formation } & \multirow{2}{*}{$(1-10)$} & Dughum member (low suitability) & 1 \\
\hline & & Rufa Formation (higher suitability) & 10 \\
\hline \multirow{2}{*}{ Crevasses/Faults } & \multirow{2}{*}{$(1-10)$} & less than $1 \mathrm{~km}$ (low suitability) & 1 \\
\hline & & more than $22 \mathrm{~km}$ (higher suitability) & 10 \\
\hline \multirow{2}{*}{ Wells } & \multirow{2}{*}{$(1-10)$} & less than 1 km (low suitability) & 1 \\
\hline & & more than $9 \mathrm{~km}$ (higher suitability) & 10 \\
\hline \multirow{2}{*}{ Environmental Areas } & \multirow{2}{*}{$(1-10)$} & less than $1 \mathrm{~km}$ (low suitability) & 1 \\
\hline & & more than $23 \mathrm{~km}$ (higher suitability) & 10 \\
\hline \multirow{2}{*}{ Power Lines } & \multirow{2}{*}{$(1-10)$} & less than 1 km (low suitability) & 1 \\
\hline & & more than $30 \mathrm{~km}$ (higher suitability) & 10 \\
\hline
\end{tabular}




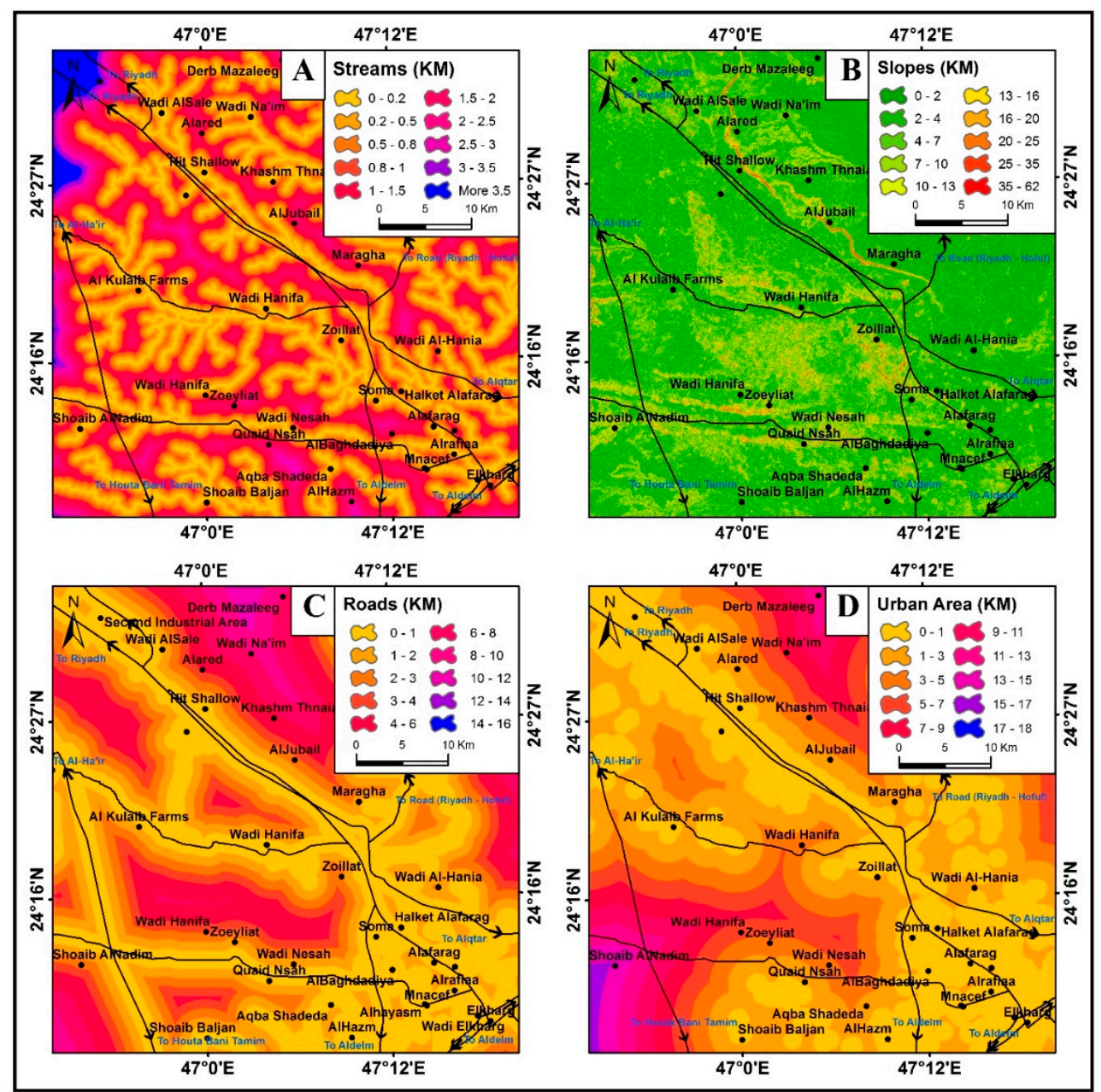

Figure 6. The distance ranges (part 1): (A) streams/valleys, (B) earth surface slopes, (C) road networks, (D) urban areas. 


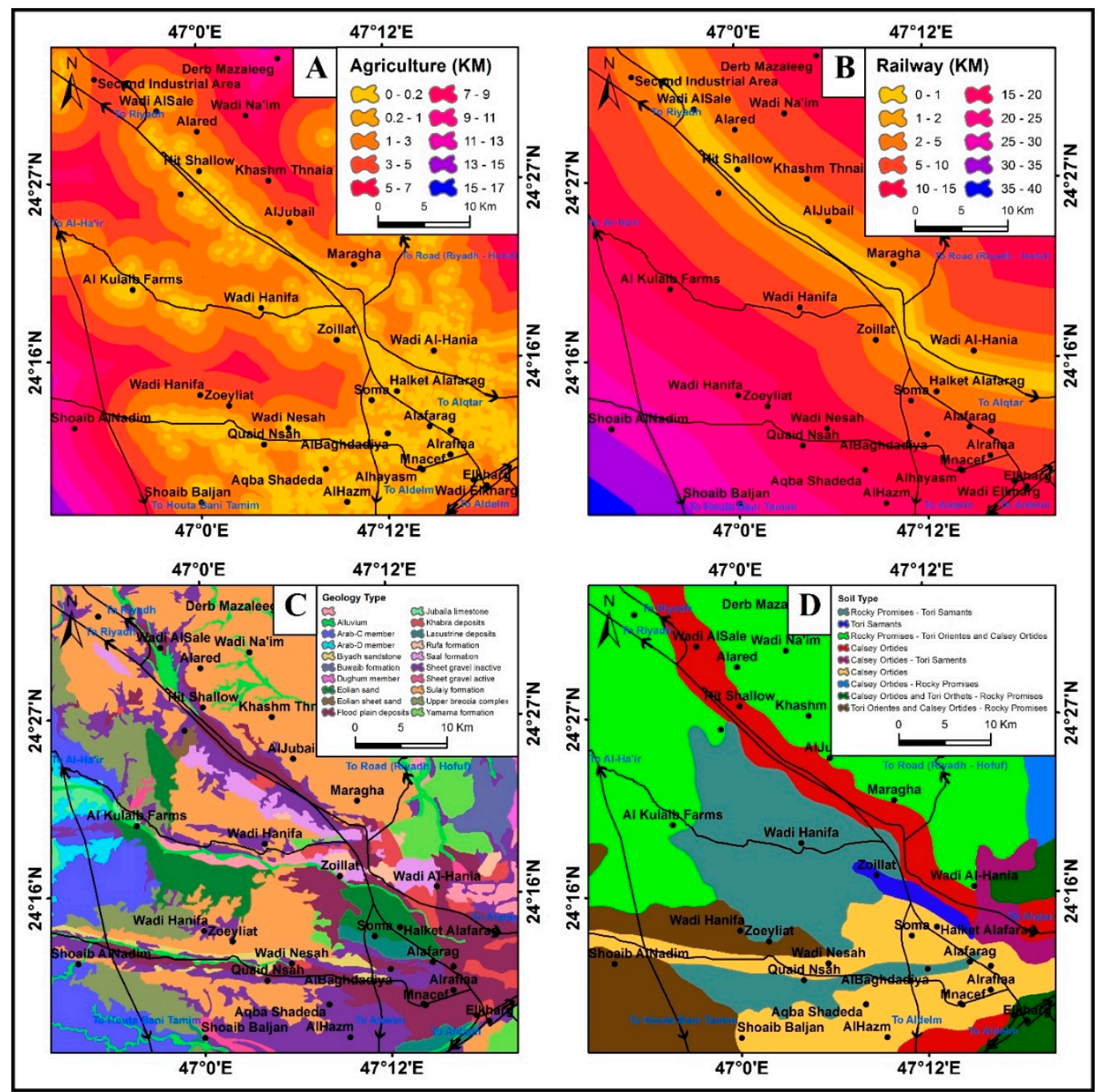

Figure 7. The distance ranges (part 2): (A) agriculture areas, (B) railways, (C) geology, (D) soil type. 


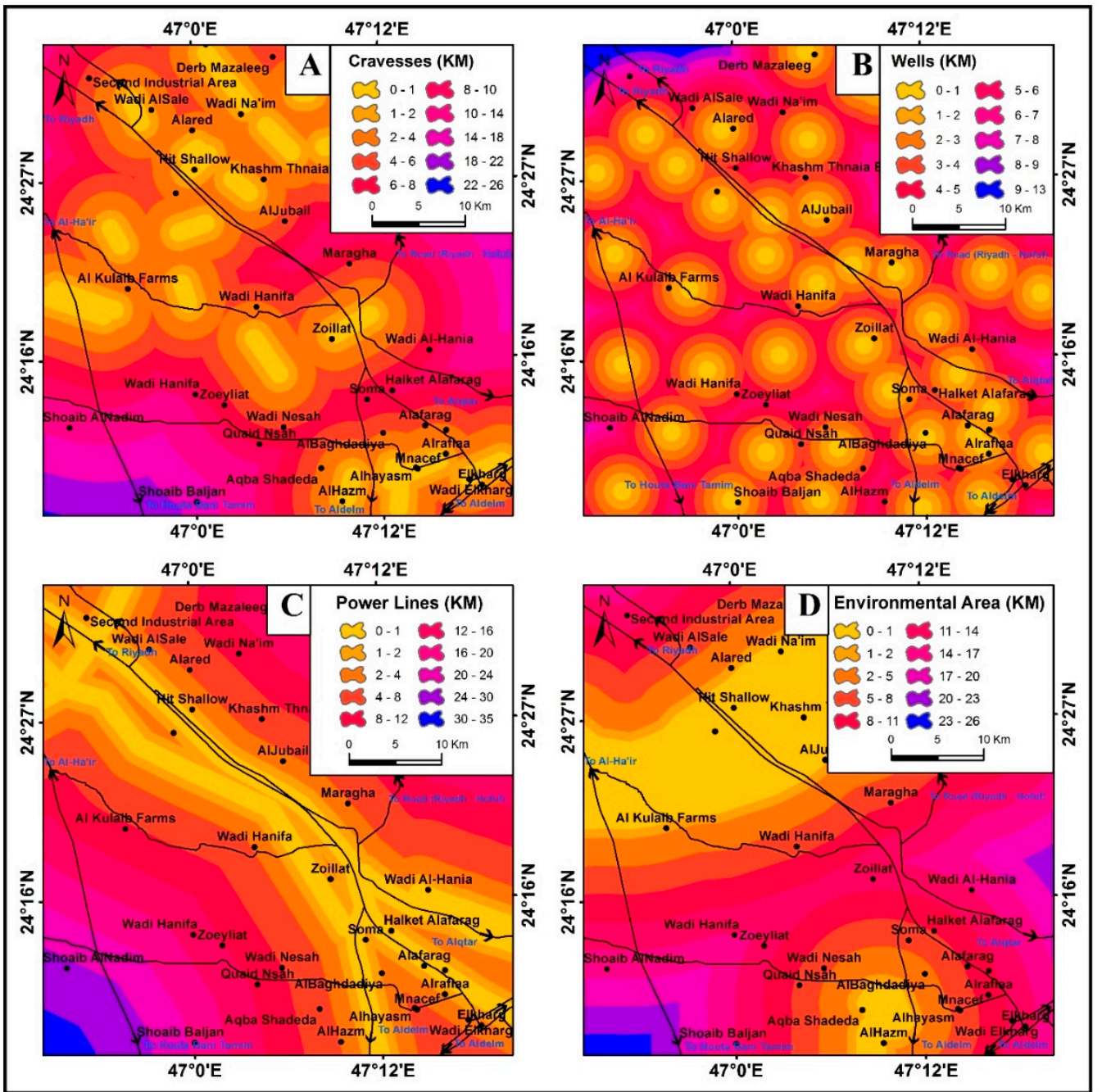

Figure 8. The distance ranges (part 3): (A) crevasses/faults, (B) water sources, (C) power lines, (D) environmental areas.

\subsection{Criteria Weighing}

The process of giving weights for the criteria of the study is one of the most sensitive points in this type of analysis; the Analytic Hierarchy Process (AHP) method was used for criteria weights, as this method proved its high efficiency in solving complex problems [75]. It was introduced by Thomas Saaty (Table 3) and is very helpful in decision making.

Table 3. The Analytic Hierarchy Process (AHP) method after Thomas Saaty.

\begin{tabular}{cc}
\hline The Weight or Preference Index & Explanation of How Important a Parameter Compared to Another \\
\hline 1 & Equally important \\
\hline 3 & Moderately more important \\
\hline 5 & Strongly more important \\
\hline 7 & Very strongly more important \\
\hline 9 & Overwhelmingly more important \\
\hline $2-4-6-8$ & Inter between weights can be used in the pairwise comparisons \\
\hline
\end{tabular}

The AHP technique has gone through successive stages of generating the pairwise comparison matrix with criteria values from 1 to 9 as the previous table (Table 3). All values in the diameter must 
equal 1 as they represent the comparison of one criterion against itself. Values above the diameter are the inverse of that below it. After the numerical comparison, the sum of the columns is obtained and then divided by the total sum to obtain the relative weight.

\subsubsection{The First Stage: Giving the Criteria Preferences Values Based on Thomas Saaty Table}

The preferences are determined in the AHP method based on pairwise comparisons that are based on evaluating each element/criterion against all the other elements/criteria in a specific hierarchal level. The element is a specific character, such as a variable or evaluation parameter, and the reference comparison point is a higher element in the hierarchal chain.

$$
\begin{gathered}
{\left[a_{i j}\right], \text { where } i, j=1,2, \ldots n,} \\
a_{i j}=1 \text { for } i=j, \\
a_{i j}=\frac{1}{a_{j i}} \text { for } i \neq j .
\end{gathered}
$$

The preferences matrix is a result of pairwise comparison of all the elements in a specific hierarchy level. Formula (1) indicates a matrix of $n^{*} n$ dimensions where $(n)$ is the number of elements that were compared.

Formula (2) is an expression of the principle of preference, in which two identical elements compared to each other are not differentiated by preference, and the difference in preferences is expressed by the number 1 , so all the values of the elements on the diameter of the matrix are equal to 1.

In the AHP, it is supposed that the preferences are alternated (Formula 3); if we suppose that (i) is $(x)$ times more important than $(j)$, it is automatically supposed that element $(j)$ is $(1 / x)$ times the importance of element $(i)$.

In the pairwise comparisons of the elements $(n)$ it is enough to provide the comparison values above the diameter in the matrix (A), the rest of the values are filled automatically for the diameter and inversed below the diameter. The total number of required comparisons equal $(n(n-1)) / 2$. Comparison between one service against all of the services is performed and the comparison value is presented in a

\begin{tabular}{|c|c|c|c|c|c|c|c|c|c|c|c|c|}
\hline Service & $S$ & $\mathbf{V}$ & $\mathbf{U}$ & $\mathbf{R}$ & RW & A & SO & $G$ & $\mathrm{C}$ & $\mathbf{W}$ & $E$ & $\mathbf{P}$ \\
\hline$S$ & 1 & 1 & 2 & 3 & 4 & 5 & 6 & 6 & 7 & 8 & 9 & 9 \\
\hline $\mathrm{V}$ & 1 & 1 & 2 & 3 & 4 & 5 & 6 & 6 & 7 & 8 & 9 & 9 \\
\hline $\mathrm{U}$ & 0.5 & 0.5 & 1 & 2 & 3 & 4 & 5 & 5 & 6 & 7 & 8 & 8 \\
\hline $\mathrm{R}$ & 0.33 & 0.33 & 0.5 & 1 & 2 & 3 & 4 & 4 & 5 & 6 & 7 & 8 \\
\hline RW & 0.25 & 0.25 & 0.33 & 0.5 & 1 & 2 & 3 & 3 & 4 & 5 & 6 & 7 \\
\hline A & 0.2 & 0.2 & 0.25 & 0.33 & 0.5 & 1 & 2 & 2 & 3 & 4 & 5 & 6 \\
\hline $\mathrm{SO}$ & 0.17 & 0.17 & 0.2 & 0.25 & 0.33 & 0.5 & 1 & 1 & 2 & 3 & 4 & 5 \\
\hline G & 0.17 & 0.17 & 0.2 & 0.25 & 0.33 & 0.5 & 1 & 1 & 2 & 3 & 4 & 5 \\
\hline$C$ & 0.14 & 0.14 & 0.17 & 0.2 & 0.25 & 0.33 & 0.5 & 0.5 & 1 & 2 & 3 & 4 \\
\hline $\mathrm{W}$ & 0.13 & 0.13 & 0.14 & 0.17 & 0.2 & 0.25 & 0.33 & 0.33 & 0.5 & 1 & 2 & 3 \\
\hline $\mathrm{E}$ & 0.11 & 0.11 & 0.13 & 0.14 & 0.17 & 0.2 & 0.25 & 0.25 & 0.33 & 0.5 & 1 & 2 \\
\hline $\mathrm{P}$ & 0.11 & 0.11 & 0.13 & 0.13 & 0.14 & 0.17 & 0.2 & 0.2 & 0.25 & 0.33 & 0.5 & 1 \\
\hline Sum & 4.11 & 4.11 & 7.05 & 10.97 & 15.92 & 21.95 & 29.28 & 29.28 & 38.08 & 47.83 & 58.5 & 67 \\
\hline
\end{tabular}
matrix (Table 4).

Table 4. The preferences values of the criteria using the AHP method. 
3.4.2. The Second Stage: The Percentage of the Preference Value for Each Parameter

A-Percentage of preference values:

The percentage of preference values between two parameters-one in a column and the other in a row-can be determined using the formula:

$$
\bar{a}_{j k}=\frac{a_{j k}}{\sum_{1=I}^{m} a_{I k}}
$$

where:

$\bar{a}_{j k}$ : The percentage of preference between two parameters in column and row.

$a_{j k}$ : The values of preference between two parameters in column and row.

$\sum_{1=I}^{m} a_{I k}$ : The total sum of the column parameter.

All the percentages for all the parameters were computed and presented in Table 5 .

Table 5. The percentages of the preferences values using the AHP method.

\begin{tabular}{ccccccccccccc}
\hline Service & $\mathbf{S}$ & $\mathbf{V}$ & $\mathbf{U}$ & $\mathbf{R}$ & $\mathbf{R W}$ & $\mathbf{A}$ & $\mathbf{S O}$ & $\mathbf{G}$ & $\mathbf{C}$ & $\mathbf{W}$ & $\mathbf{E}$ & $\mathbf{P}$ \\
\hline $\mathbf{S}$ & 0.243 & 0.243 & 0.284 & 0.273 & 0.251 & 0.228 & 0.205 & 0.205 & 0.184 & 0.167 & 0.154 & 0.134 \\
\hline $\mathbf{V}$ & 0.243 & 0.243 & 0.284 & 0.273 & 0.251 & 0.228 & 0.205 & 0.205 & 0.184 & 0.167 & 0.154 & 0.134 \\
\hline $\mathbf{U}$ & 0.122 & 0.122 & 0.142 & 0.182 & 0.188 & 0.182 & 0.171 & 0.171 & 0.158 & 0.146 & 0.137 & 0.119 \\
\hline $\mathbf{R}$ & 0.080 & 0.080 & 0.071 & 0.091 & 0.126 & 0.137 & 0.137 & 0.137 & 0.131 & 0.125 & 0.120 & 0.119 \\
\hline $\mathbf{R W}$ & 0.061 & 0.061 & 0.047 & 0.046 & 0.063 & 0.091 & 0.102 & 0.102 & 0.105 & 0.105 & 0.103 & 0.104 \\
\hline $\mathbf{A}$ & 0.049 & 0.049 & 0.035 & 0.030 & 0.031 & 0.046 & 0.068 & 0.068 & 0.079 & 0.084 & 0.085 & 0.090 \\
\hline SO & 0.041 & 0.041 & 0.028 & 0.023 & 0.021 & 0.023 & 0.034 & 0.034 & 0.053 & 0.063 & 0.068 & 0.075 \\
\hline $\mathbf{G}$ & 0.041 & 0.041 & 0.028 & 0.023 & 0.021 & 0.023 & 0.034 & 0.034 & 0.053 & 0.063 & 0.068 & 0.075 \\
\hline $\mathbf{C}$ & 0.034 & 0.034 & 0.024 & 0.018 & 0.016 & 0.015 & 0.017 & 0.017 & 0.026 & 0.042 & 0.051 & 0.060 \\
\hline $\mathbf{W}$ & 0.032 & 0.032 & 0.020 & 0.015 & 0.013 & 0.011 & 0.011 & 0.011 & 0.013 & 0.021 & 0.034 & 0.045 \\
\hline $\mathbf{E}$ & 0.027 & 0.027 & 0.018 & 0.013 & 0.011 & 0.009 & 0.009 & 0.009 & 0.009 & 0.010 & 0.017 & 0.030 \\
\hline $\mathbf{P}$ & 0.027 & 0.027 & 0.018 & 0.012 & 0.009 & 0.008 & 0.007 & 0.007 & 0.007 & 0.007 & 0.009 & 0.015 \\
\hline Sum & 1 & 1 & 1 & 1 & 1 & 1 & 1 & 1 & 1 & 1 & 1 & 1 \\
\hline
\end{tabular}

B-Values of the relative weights:

The relative weights values are determined using the formula:

$$
w_{j}=\frac{\sum_{1=I}^{m} a_{j l}}{m}
$$

where:

$w_{j}$ : The value of the relative weight for the row parameter.

$\sum_{1=I}^{m} a_{j l}$ : Sum of the percentages of the preference values for a row parameter.

$m$ : The final value of the sum $\sum_{1=I}^{m} a j l$ for all rows, Table 6 shows the final weights. 
Table 6. The relative weights of criteria using the AHP method.

\begin{tabular}{ccc}
\hline Service & Sum of the Row & The Relative Weight \\
\hline S & 2.572 & 0.214 \\
\hline V & 2.572 & 0.214 \\
\hline U & 1.840 & 0.153 \\
\hline R & 1.354 & 0.113 \\
\hline RW & 0.990 & 0.082 \\
\hline A & 0.714 & 0.059 \\
\hline SO & 0.504 & 0.042 \\
\hline G & 0.504 & 0.042 \\
\hline C & 0.354 & 0.030 \\
\hline W & 0.258 & 0.022 \\
\hline E & 0.188 & 0.016 \\
\hline P & 0.151 & 0.013 \\
\hline Sum & 12 & 1 \\
\hline
\end{tabular}

3.4.3. The Third Stage: Consistency Verification Index for Calculating the Consistency Mathematically

Firstly: the consistency is computed using the formula:

$$
C I=\frac{\kappa M a x-n}{n-1}
$$

where:

КMax: The square root of the pairwise comparison matrix mean

$\mathrm{n}$ : The number of parameters or criteria

$$
C I=\frac{8.7-8}{8-1}=0.1
$$

The closer the result to zero, the more confident the consistency index and vice versa.

Secondly: calculating the consistency index percent from the formula:

$$
\text { Stability ratio }=\frac{C I}{R}
$$

where $\mathrm{R}$ is the random consistency index based on the number of criteria taken from Table 7.

Table 7. Random Stability Index.

\begin{tabular}{ccccccccccc}
\hline $\mathbf{N}$ & $\mathbf{1}$ & $\mathbf{2}$ & $\mathbf{3}$ & $\mathbf{4}$ & $\mathbf{5}$ & $\mathbf{6}$ & $\mathbf{7}$ & $\mathbf{8}$ & $\mathbf{9}$ & $\mathbf{1 0}$ \\
\hline $\mathrm{R}$ & 0 & 0 & 0.52 & 0.89 & 1.11 & 1.25 & 1.3 & 1.4 & 1.45 & 1.49 \\
\hline
\end{tabular}

The value of the random consistency index based on the previous table is equal to 1.49 , because the criteria used are more than 10 . The percent of the consistency index is $0.07 / 1.49=5 \%=0.05$.

The consistency values must be in a consistent range not exceeding 0.1 (i.e., $10 \%$ ), as the higher the value is than 0.1 , the more conflict in consistency. 


\section{Results and Discussion}

4.1. Planning and Determining the Optimum Locations for Constructing New Urban Areas in the Rural-Urban Continuum (Ar Riyadh-Al Kharj)

The details of the spatial suitability maps analysis (Figures 9-11 and Table 8) of the used criteria for determining the best locations for constructing new urban areas in the rural-urban continuum (Ar Riyadh-Al Kharj) are as follows:

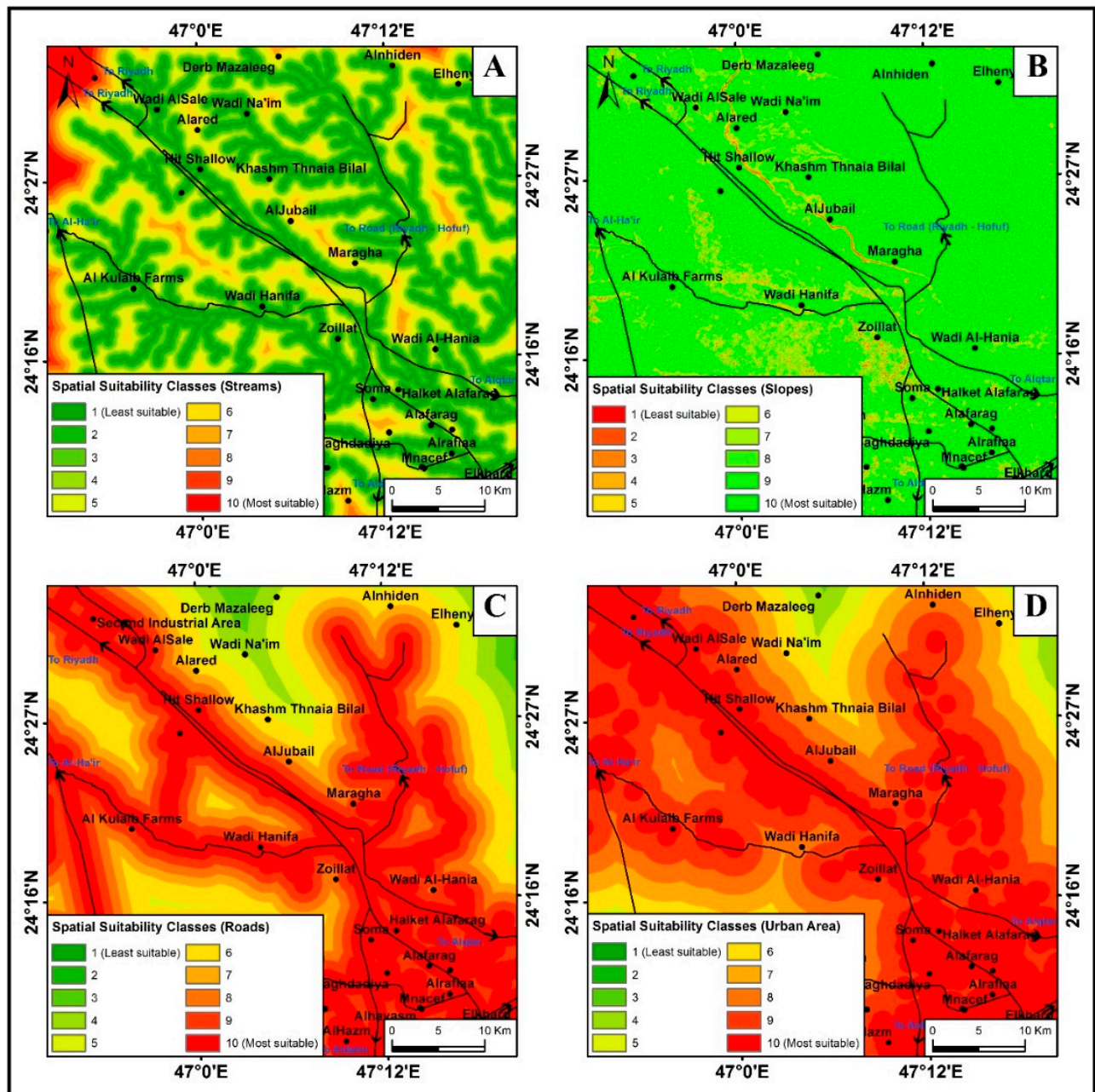

Figure 9. The spatial suitability (part 1) of (A) streams/valleys, (B) earth surface slopes, (C) road networks, (D) urban areas. 


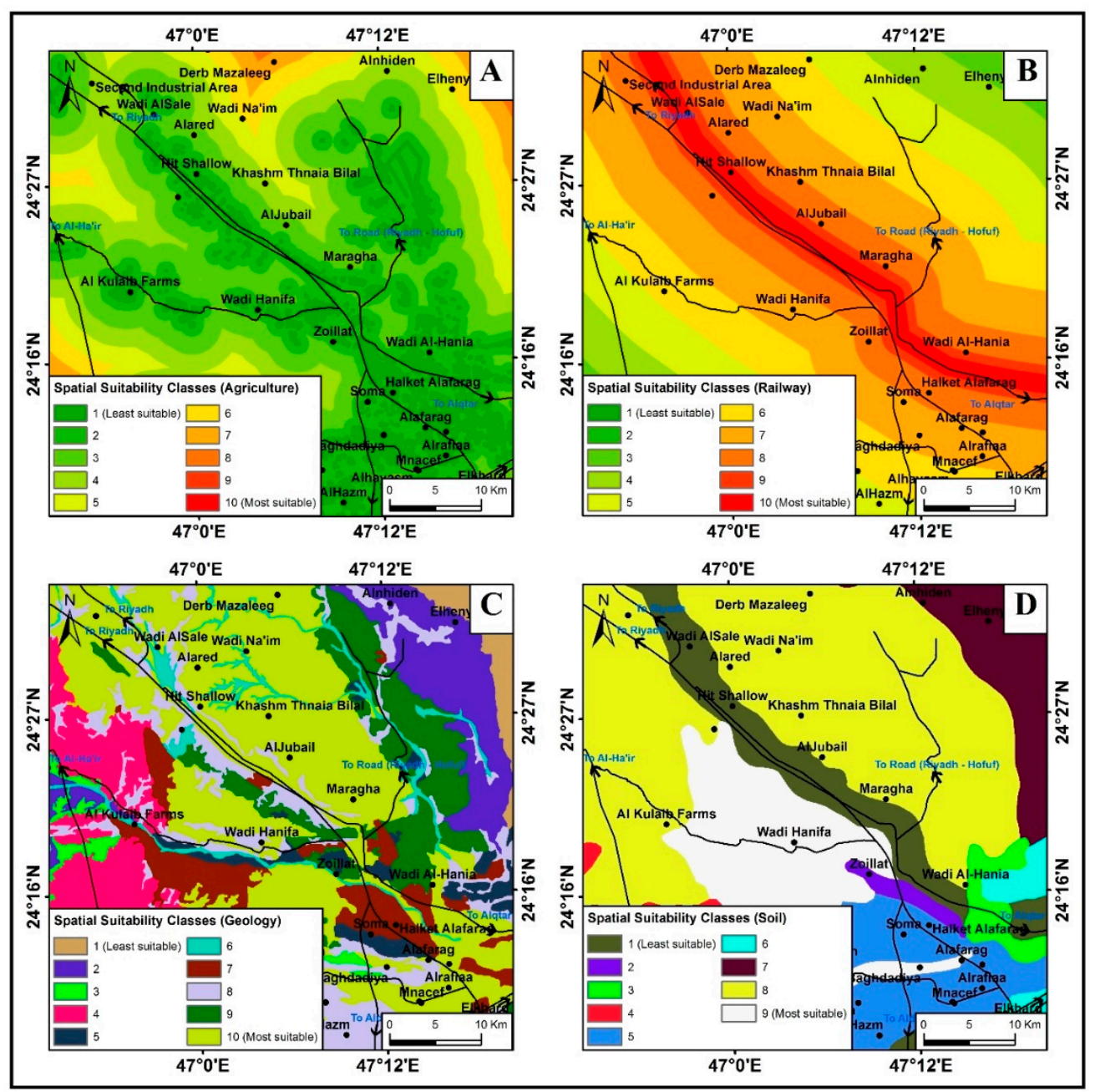

Figure 10. The spatial suitability (part 2) of (A) agriculture areas, (B) railways, (C) geology, (D) soil type. 


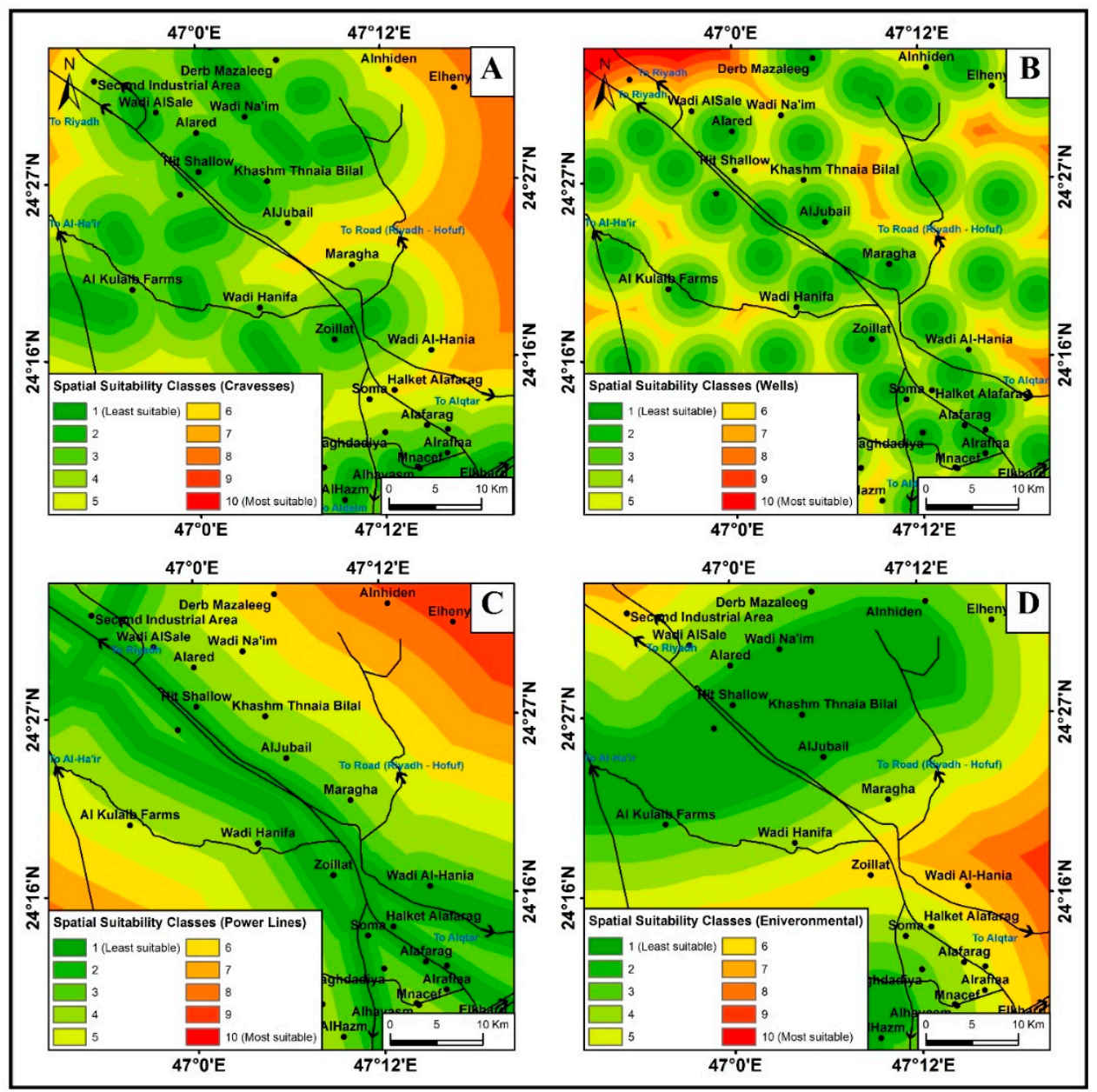

Figure 11. The spatial suitability (part 3) of (A) crevasses/faults, (B) water sources, (C) power lines, (D) environmental areas.

Table 8. The spatial suitability analysis results for the different criteria affecting the rural-urban continuum area between Ar Riyadh and Al Kharj.

\begin{tabular}{|c|c|c|c|c|c|c|c|}
\hline \multirow{2}{*}{ m } & \multirow{2}{*}{ Parameter } & \multicolumn{3}{|c|}{ Areas of Low Spatial Suitability } & \multicolumn{3}{|c|}{ Areas of High Spatial Suitability } \\
\hline & & Category & $\begin{array}{c}\text { Area } \\
\left(\mathbf{k m}^{2}\right)\end{array}$ & $\%$ & Category & $\begin{array}{c}\text { Area } \\
\left(\mathrm{km}^{2}\right)\end{array}$ & $\%$ \\
\hline 2 & Streams/Valleys & less than $0.5 \mathrm{~km}$ & 1082.87 & 39.8 & more than $3 \mathrm{~km}$ & 75.94 & 2.79 \\
\hline 5 & Railways & more than $30 \mathrm{~km}$ & 93.41 & 3.43 & less than $2 \mathrm{~km}$ & 250.25 & 9.2 \\
\hline 6 & $\begin{array}{c}\text { Agriculture } \\
\text { Areas }\end{array}$ & less than $1 \mathrm{~km}$ & 988.59 & 36.34 & more than $13 \mathrm{~km}$ & 19.52 & 0.72 \\
\hline 7 & Soil Type & $\begin{array}{l}\text { calcic orthider, } \\
\text { torry samantas }\end{array}$ & 269.18 & 9.89 & $\begin{array}{l}\text { (torry samantas + rock fragments and } \\
\text { notches) and orthider + torry } \\
\text { orthider+ rock fragments and notches) }\end{array}$ & 1493.87 & 54.91 \\
\hline 9 & Crevasses/Faults & less than $2 \mathrm{~km}$ & 459.95 & 16.91 & more than $18 \mathrm{~km}$ & 92.88 & 3.41 \\
\hline 10 & Wells & less than $2 \mathrm{~km}$ & 535.11 & 19.67 & more than $8 \mathrm{~km}$ & 46.59 & 1.71 \\
\hline 11 & $\begin{array}{c}\text { Environmental } \\
\text { Areas }\end{array}$ & less than $2 \mathrm{~km}$ & 680.62 & 25.2 & more than $20 \mathrm{~km}$ & 85.88 & 3.16 \\
\hline 12 & Power Lines & less than $2 \mathrm{~km}$ & 633.95 & 23.3 & more than $24 \mathrm{~km}$ & 213.74 & 7.86 \\
\hline
\end{tabular}




\subsubsection{The Spatial Suitability of the "Slopes"}

The Advanced GIS techniques and the availability of high resolution Digital Elevation Models (DEMs) beside the radar based elevation models contributed to the enhancement of selecting locations for urban development [76,77]. A resolution of $12 \mathrm{~m}$ DEM was obtained from the Vertex website of NASA. With a range of urban-rural hub selections ranging from 366 to $576 \mathrm{~m}$, the northern part of the axis is characterized by a height difference from the southern part, with the north half ranging from 492 to $576 \mathrm{~m}$, while the southern part ranges from 366 to $492 \mathrm{~m}$; the most famous mountains are Jabal Jubail in the west, the Mountains of Um al-Shaal, and the Zuwailia Mountains in the east.

The spatial suitability map was divided into suitability categories; areas of high spatial suitability are those of gentle slopes, while areas with steep slopes are of low spatial suitability. Areas with lower spatial suitability are those with slopes of more than 25 degrees, they are represented by a scarp extending from the north to the southeast of the study area and also some scattered areas in the middle of the study area having a total area of $6.49 \mathrm{~km}^{2}$ representing $0.24 \%$ of the area of the study area. Areas with higher spatial suitability are those with slopes of less than 4 degrees, they constitute an area of $1589.31 \mathrm{~km}^{2}(58.75 \%)$ (Figure 9 and Table 8 ).

\subsubsection{The Spatial Suitability of "Streams"}

Determining areas that are subjected to flash flood hazards, enhancing the flash flood maps for the urban areas based on geomatics and hydrological modeling is a main issue in the urban planning process for sustainability [78,79]. The urban-rural hub area has some of major valleys the major valleys in the Kingdom of Saudi Arabia, namely wadi al-Sli, which controls about $65 \%$ of the axis, followed by Wadi Hanifa with $35 \%$.

The longer the distance away from streams, the higher the spatial suitability and vice versa. Areas with lower spatial suitability are those with a distance of less than $0.5 \mathrm{~km}$ from streams, these areas constitute a total area of $1082.87 \mathrm{~km}^{2}$ representing $39.8 \%$ of the area of the study area. Areas with higher spatial suitability are those with a distance of more than $3 \mathrm{~km}$ away from streams, they constitute an area of $75.94 \mathrm{~km}^{2}(2.79 \%)$ (Figure 9 and Table 8 ).

\subsubsection{The Spatial Suitability of "Urban Areas"}

The evaluation of land suitability includes selecting the suitable locations for urban development through defining the suitability index of a specific predefined area [55]. Urban communities in their broad sense include all human housing, whether stable (fixed) such as urban, rural, deserted, or unstable communities such as "Badia" (Bedouin camps), the most important urban communities are Al-Amaj, Al-Rifai, Bajadia, Al-Qalib farms, Hit, and south Hit, and Al Badia.

The closer the land to urban areas, the higher the spatial suitability and vice versa. Areas with higher suitability are those with a distance of less than $3 \mathrm{~km}$ from urban areas, these consist of and area of $1569.24 \mathrm{~km}^{2}$, comprising $57.86 \%$ of the total area of the study area. Areas with lower spatial suitability are those with a distance of more than $15 \mathrm{~km}$ from the urban areas, these make up an area of $24.1 \mathrm{~km}^{2}(0.89 \%)$, (Figure 9 and Table 8 ).

\subsubsection{The Spatial Suitability of "Roads Networks"}

The suitability analysis for urban development comprises the road networks analysis is one of the most efficient techniques in determining the best locations for urban development using different criteria and weights [80]. Riyadh Al Kharj Road represents the largest part of the axis by up to $90 \%$, in addition to the Al Kharj Haradh Road and Riyadh Dalm Road. The closer to road networks, the higher the spatial suitability and vice versa. Areas with higher suitability are those of a distance less than 2 $\mathrm{km}$ from road networks, these comstitute an area $1450.68 \mathrm{~km}^{2}$ with $53.32 \%$ of the total of the study area. Areas with lower spatial suitability are those with a distance of more than $12 \mathrm{~km}$ away from the road networks, these areas are of $16.41 \mathrm{~km}^{2}(0.6 \%)$, (Figure 9 and Table 8 ). 


\subsubsection{The Spatial Suitability of "Railways"}

The Riyadh-Dammam train track, which comes north from Riyadh and then passes north of $\mathrm{Al}$ Kharj city, runs up to $70 \mathrm{~km}$ long, and then heads to the eastern region. The closer to railways, the higher the spatial suitability and vice versa. Areas with higher suitability are those with adistance of less than $2 \mathrm{~km}$ from railways, these constitute an area of $250.25 \mathrm{~km}^{2}$ with $9.2 \%$ of the total area of the study area. Areas with lower spatial suitability are those with a distance of more than $30 \mathrm{~km}$ away from the railways, these constitute an area of $93.41 \mathrm{~km}^{2}(3.43 \%)$ (Figure 10 and Table 8).

\subsubsection{The Spatial Suitability of "Agriculture Areas"}

Areas surrounding cities are favorable for resettlement by most of the urban population due to the existence of the main agriculture areas and being near to workplaces in cities [10]. Agricultural land is concentrated in the north and northwest of Al Kharj city by $80 \%$ where the region is famous for agriculture because of the availability of arable soils, water sources of wells, and rainwater that supplies the region with its needs in the field of agriculture. The closer to agricultural areas, the lower the spatial suitability and vice versa. The lower suitability categories are those with a distance of less than $1 \mathrm{~km}$ from agriculture areas, constituting an area of $988.59 \mathrm{~km}^{2}(36.34 \%)$. The higher suitability categories are those with a distance of more than $13 \mathrm{~km}$ from agriculture areas, constituting $19.52 \mathrm{~km}^{2}$ $(0.72 \%)$ (Figure 10 and Table 8$)$.

\subsubsection{The Spatial Suitability of "Soil Type"}

The urban-rural region is heavily affected by the calci-ortieds soil type by $55 \%$, followed by the rock protrusions (torry Samments) by 30\%, and the rock profiles (torry Orthants and calcic orthider) at $15 \%$. Areas with lower spatial suitability are those with loose friable soils, while areas with high spatial suitability are those of hard compact soils. The lower suitability categories comprise the calcic orthider soils (deep mud soils) and torry samantas soil (sand dunes), constituting an area of $269.18 \mathrm{~km}^{2}$ representing $9.89 \%$ of the total area of the study area. While the higher suitability categories comprise soils composed of torry samantas + rock fragments and notches and soils composed of calcic orthider + torry orthider+ rock fragments and notches, constituting an area of $1493.87 \mathrm{~km}^{2}(54.91 \%)$ (Figure 10 and Table 8).

\subsubsection{The Spatial Suitability of "Geology"}

The urban-rural caller area is heavily affected by the geological structure of the sediment salutations, where it represents $70 \%$ of the area of the urban-rural connection axis due to the impact of the Valley of The Sly and its proximity to the axis, followed by the geological composition of the gravel layer which is $10 \%$ inactive, followed by hydration Geological sand by $10 \%$, and the composition of Sulaiy by $10 \%$. Areas of lower spatial suitability are those of sandy and silty geologic formations, while areas of higher spatial suitability are those of hard compact massive geologic formations. The geologic map was divided into suitability categories; the lower suitability categories were that of Dughum formation that constitute an area of $310.04 \mathrm{~km}^{2}$ representing $11.4 \%$ of the total area of the study area, while the higher suitability categories were that of alluvial plain and Sulaiy formations that constitute an area of $1227.47 \mathrm{~km}^{2}(45.12 \%)$, (Figure 10 and Table 8 ).

\subsubsection{The Spatial Suitability of "Crevasses"}

The rifts are concentrated largely in the north-western part of the axis, accounting for $35 \%$ of the total rifts and the rest of the rifts are spread in at different locations in the west by $20 \%$, and in the south by $15 \%$. Areas closer to crevasses have a lower suitability and vice versa. The distance map of crevasses was divided into suitability categories including the lower suitability categories with a distance of less than $2 \mathrm{~km}$ from crevasses constituting $459.95 \mathrm{~km}^{2}(16.91 \%)$, the higher suitability 
categories are those withdistances of more than $18 \mathrm{~km}$ from crevasses, constituting an area of 92.88 $\mathrm{km}^{2}(3.41 \%)$ (Figure 11 and Table 8$)$.

\subsubsection{The Spatial Suitability of "Wells"}

Wells are concentrated largely in the urban-rural area of The Axis of Urban Contact near the urban cluster areas, where they are concentrated largely in the south and south-west by $40 \%$ near the city of Al Kharj, as well as near Ar Riyadh city by about $30 \%$, and about $20 \%$ scattered around the axis of the rural caller Urban.

Areas closer to wells are with lower spatial suitability and vice versa. The distance map of wells was divided into suitability categories; the lower suitability categories are those with a distance of less than $2 \mathrm{~km}$ from wells, constituting an area of $535.11 \mathrm{~km}^{2}(19.67 \%)$, the higher suitability categories are those with a distance of more than $8 \mathrm{~km}$ from wells, constituting an area of $46.59 \mathrm{~km}^{2}(1.71 \%)$ (Figure 11 and Table 8).

\subsubsection{The Spatial Suitability of "Environmental Areas"}

Protection of the environmental and natural resources is regarded as having high importance, especially in the witnessed urban crawling [81]. The environmental areas are concentrated on the urban rural hub in the south of Riyadh by $40 \%$, intersecting with the axis from east to west, and in the south by $10 \%$ west of $\mathrm{Al}$ Kharj.

Areas closer to environmental areas have low spatial suitability and vice versa. The distance map of environmental areas was divided into categories of suitability; the lower suitability categories are those of distance less than $2 \mathrm{~km}$ from the environmental areas constituting $680.62 \mathrm{~km}^{2}$ area (25.2\%), the higher suitability categories are those with a distance of more than $20 \mathrm{~km}$ from environmental areas, constituting an area of $85.88 \mathrm{~km}^{2}(3.16 \%)$ (Figure 11 and Table 8 ).

\subsubsection{The Spatial Suitability of "Power Lines"}

Accessibility to main facilities and utilities such as electricity and drinking water are of great importance and regarded the main influencing parameters in the selection of urban areas for development [82]. The power lines are concentrated parallel to the urban rural connection axis from Riyadh in the north to Al Kharj in the south, as well as another power line that runs along the main line of the urban rural connection hub. Areas closer to power lines have low spatial suitability and vice versa. The distance map of power lines was divided into categories of suitability; the lower suitability categories are those with a distance of less than $2 \mathrm{~km}$ from power lines, constituting an area of $633.95 \mathrm{~km}^{2}(23.3 \%)$, the higher suitability categories are those with a distance of more than $24 \mathrm{~km}$ from environmental areas, constituting an area of $213.74 \mathrm{~km}^{2}(7.86 \%)$ (Figure 11 and Table 8).

\subsection{Analysis of the Suitability Maps for Constructing New Urban Areas in ArRiyadh-Al kharj Rural-UrbanContinuum}

The final result of spatial suitability maps (Figures 12 and 13 and Table 9) for constructing new urban areas in the Ar Riyadh-Al kharj urban-rural continuum area revealed that there are five categories of spatial suitability based on several criteria. These categories are the following: 
Table 9. Relative importance to spatial suitability for constructing new urban areas in the Ar Riyadh-Al kharj urban-rural continuum.

\begin{tabular}{ccccc}
\hline $\mathbf{M}$ & Suitability Degree & Suitability Percentage & Area $\mathbf{( k m}^{\mathbf{2}} \mathbf{~}$ & $\mathbf{\%}$ \\
\hline 1 & Very High & $66-86 \%$ & 511.45 & $18.8 \%$ \\
\hline 2 & High & $62-66 \%$ & 731.27 & $26.88 \%$ \\
\hline 3 & Moderate & $57-62 \%$ & 820.5 & $30.16 \%$ \\
\hline 4 & Low & $51-57 \%$ & 491.59 & $18.07 \%$ \\
\hline 5 & Very Low & $32-51 \%$ & 165.68 & $6.09 \%$ \\
\hline Total & & 2720.5 & $100 \%$ \\
\hline
\end{tabular}

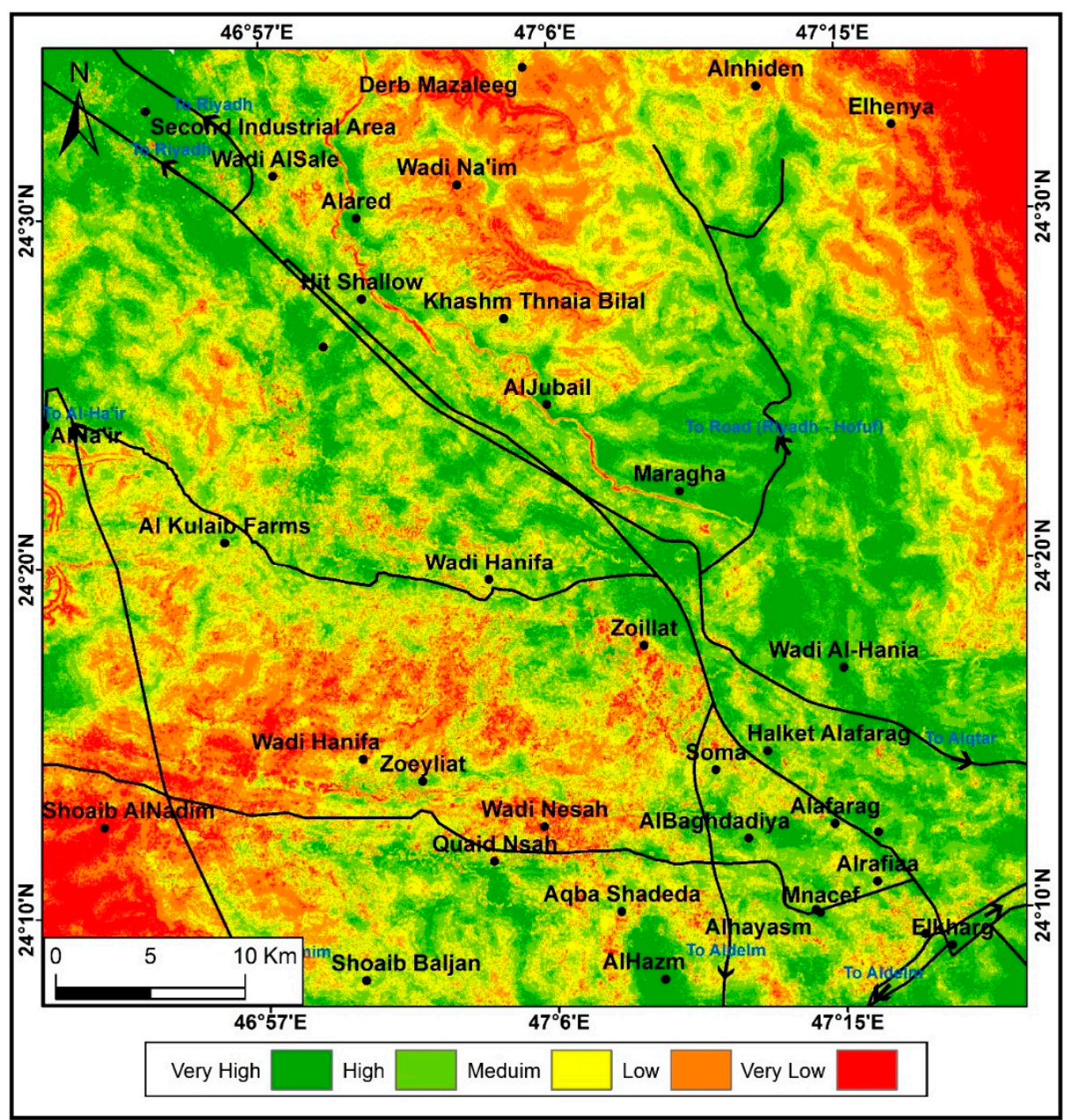

Figure 12. The final spatial suitability map for sustainable urban development in the rural-urban continuum (Ar Riyadh-Al Kharj), 2019. 


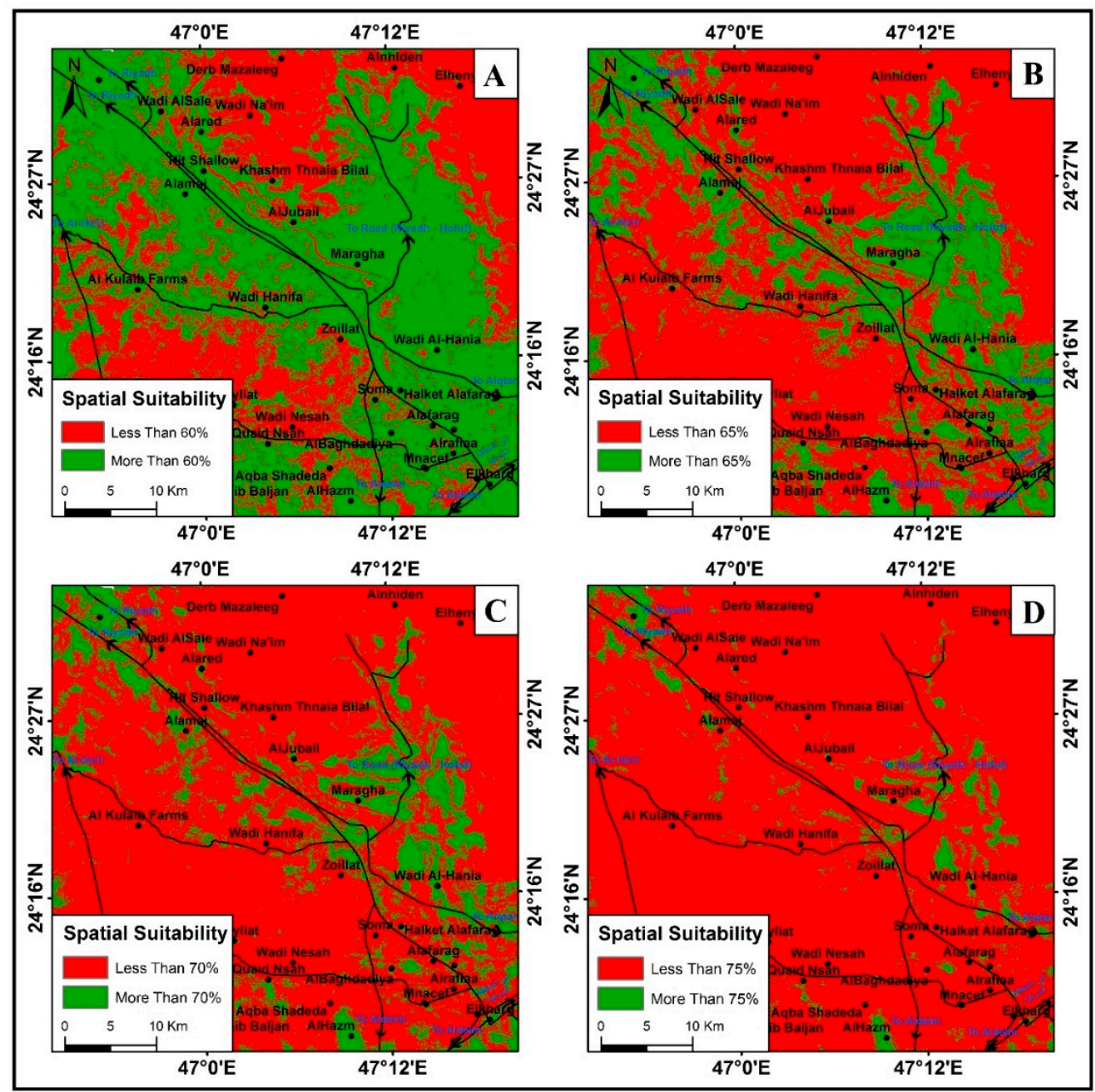

Figure 13. Levels of spatial suitability for sustainable urban development in the rural-urban continuum (Ar Riyadh-Al Kharj), 2019: (A) less than 60\%/more than 60\%), (B) less than 65\%/more than 65\%, (C) less than $70 \% /$ more than $70 \%$, (D) less than $75 \% /$ more than $75 \%$.

\subsubsection{Areas with Very High Spatial Suitability (66-86\% Suitability)}

The category "very high suitability" comprises areas of spatial suitability ranging from $66 \%$ to $86 \%$, constituting an area of $511.45 \mathrm{~km}^{2}$, representing $18.8 \%$ of the total area of the Ar Riyadh-Al kharj urban-rural continuum. Areas within this category are concentrated in the northwest of the study area in the urban areas of Ar Riyadh governorate, in the southeast of the area in the urban areas of Al Kharj governorate, and some scattered areas around the corridor of the road linking the Ar Riyadh and $\mathrm{Al}$ Kharj governorates, besides some localities on the eastbound roads branching from the Ar Riyadh-Al Kharj road.

\subsubsection{Areas with High Spatial Suitability (62-66\%)}

The category "high spatial suitability" comprises areas of spatial suitability ranging from $62 \%$ to $66 \%$, they constitute an area of $731.27 \mathrm{~km}^{2}$ representing $26.88 \%$ of the total area of the Ar Riyadh-Al kharj urban-rural continuum. Areas within this category are concentrated around the areas with very high spatial suitability in the northwest of the study area in the urban areas of Ar Riyadh governorate, in the southeast of the area in the urban areas of $\mathrm{Al} \mathrm{Kharj} \mathrm{governorate,} \mathrm{and} \mathrm{some} \mathrm{scattered} \mathrm{areas} \mathrm{around}$ the corridor of the linking road between Ar Riyadh and Al Kharj governorates besides some localities on the eastbound and westbound roads branching from Ar Riyadh-AlKharj road. 


\subsubsection{Areas with Moderate Spatial Suitability (57-62\%)}

The category "moderate spatial suitability" comprises areas of spatial suitability ranging from $57 \%$ to $62 \%$, they constitute an area of $820.5 \mathrm{~km}^{2}$ representing $30.16 \%$ of the total area of the Ar Riyadh-Al kharj urban-rural continuum. Areas within this category are concentrated in the south and middle of the study area.

\subsubsection{Areas with Low Spatial Suitability (51-57\%)}

The category "low spatial suitability" comprises areas of spatial suitability ranging from $51 \%$ to $57 \%$, they constitute an area of $491.59 \mathrm{~km}^{2}$, representing $18.07 \%$ of the total area of the Ar Riyadh-Al kharj urban-rural continuum. Areas within this category are concentrated in the desert areas in northeast, southwest, north, and middle of the study area.

\subsubsection{Areas with Very Low Spatial Suitability (32-51\%)}

The category "very low spatial suitability" comprises areas of spatial suitability ranging from $32 \%$ to $51 \%$, they constitute an area of $165.68 \mathrm{~km}^{2}$, representing $6.09 \%$ of the total area of the Ar Riyadh-Al kharj urban-rural continuum. Areas within this category are concentrated in the desert areas in the far northeast, far southwest, north, and middle of the study area.

\section{Recommendations}

The study recommends areas with spatial suitability upwards of $70 \%$ for urban development on the Ar Riyadh-Al kharj urban-rural continuum corridor. The study also recommends carrying out projects with high priority that support the vision of sustainable urban planning in this area.

Four local urban development areas are to be constructed and four current villages are to be upgraded to rural complexes. These projects will limit the urban development to specific areas without allowing random expansion and consequently avoiding the urban conjugation of Ar Riyadh and Al kharj cities, as recommended in the regional planning plan of Al Kharj governorate that states this area to be primarily a recreational agriculture corridor, and dealing with the fact of the existence of distributed industrial organizations and the other types of land uses to match the main purpose of the regional plan of the $\mathrm{Al}$ Kharj governorate.

Tourism and recreational land use in this corridor should be allocated in an area not exceeding $10 \%$ of the total area of the corridor, the buildings shouldn't exceed two floors in height. Parks with games cities for children and adults, different gardens and parks, tourism service centers, tourism and recreation villages including tourist settlement and camping areas provided with facilities, services and parking areas, and sports playgrounds areas are the most important suggested services to be provided in this area, besides the agriculture land uses and the high way services. Agriculture should be allowed to be divided into agriculture rests with minimum areas of 50,000 $\mathrm{m}^{2}$ each with buildings of one floor with an area of no more than $10 \%$ of the area of each rest. Industrial, commercial, and settlement land uses should no longer be allowed in this area, except within the currently existing urban complexes and the planned development projects suggested by the present study.

The industrial constructions present in this corridor should be rearranged in the form of industrial cells comprising authorized non pollutant industrial facilities by official authorities, and should be related to the source raw materials in the area. Other industrial facilities that will be reallocated to verified industrial zones shouldn't be allocated in the corridor of study.

All the industrial facilities that are polluters, and especially the non-authorized ones, should be moved to the industrial area in the Al Kharj governorate. The other authorized non pollutant industrial facilities distributed along the corridor of study should be gathered together, forming industrial cells and leaving empty places that should be used for other facilities that meet the criteria of the sustainable development plan. 
Bringing up new types of land use that may help in achieving the objective of the science of environmental planning of industrial areas, such as waste storage for collecting the wastes and side byproducts of the factories and companies and preparing them, either by recycling or classification to several types to be reused in factories in or out of the industrial area.

We recommend implementing the Decision of the Council of Ministers No. (157) dated 28 May 2007 regarding the urban zoning regulations and rules. The regulation represents a critical framework for planning projects and urban expansion in the Kingdom of Saudi Arabia. Furthermore, this regulation is considered a policy to redirect and control the urban development by setting appropriate boundaries for the settlement of urban activities, including urban expansion projects, accommodating urban growth during a specific period of time, and providing the public services and facilities.

The amendment of agricultural land uses with special conditions adopted by the Municipality should be approved to stop the random construction and urban sprawl in agricultural lands.

We recommend intensifying the control over the agricultural lands and preventing any division of these lands for residential purposes.

The establishment of workshops, factories, and other commercial warehouses should be prevented within agricultural lands.

Six months should be given as a permission deadline to correct the status of violating agricultural lands.

The violating owners with encroachment percentages exceeding $50 \%$, should be obliged to prepare plans, provide the necessary services and facilities according to the planning standards, and focus on providing lands for public utilities.

\section{Conclusions}

The present study serves national local and regional development aspect in the geographic buffer of Ar Riyadh-Al kharj urban-rural continuum, as this area forms the future of development of $\mathrm{Ar}$ Riyadh and Al kharj, in accordance with the vision and national transformation plan of KSA 2030. This can be achieved by developing the current potentialities for finding new sources of income, and by protecting the resources. The national strategic urban plan that was authorized by the ministers' committee on 29/8/2000 (decision number 127) ensured the importance of choosing development corridors to achieve the integration between all the parts of the kingdom.

Concerning the study area, the national strategic urban plan of the kingdom regarded the development corridor of Ar Riyadh-Al kharj urban-rural continuum to be one of the most important development corridors in the middle of the KSA due to having high development potentialities, including industrial, commercial, economic, and agriculture activities besides the specialized services. The rural-urban continuum of Ar Riyadh-Al kharj is of high promising potentiality for sustainable environmental economic development due to the outstanding natural characteristics, the agricultural landscapes, and the palm forests in wadis beside the astonishing visual panorama.

The rural-urban continuum between Ar Riyadh and Al Kharj suffers unclear general land uses trend due to the urban expansion at the expense of the agriculture lands, the imbalance of the population compound, the deterioration of the urban fabric, lack and poor distribution of services, dominance of the industrial land use at the expense of other uses, increase in the environmental changes, and loss of the environmental and ecological characteristics of this area between Ar Riyadh and Al Kharj cities. This makes it a must to cease the undesired activities of land uses through determining the optimum areas for the future activities of urban development in the area depending on the spatial suitability model for land uses evaluation and sustainable urban development. Projects of high priority and supporting the sustainable development plan for ensuring the sustainability of resources environmentally, economically and in the urban development, according to the KSA vision 2030 for this area as introduced in the present study.

The study presented a land use suitability map for sustainable urban development in Ar Riyadh-Al kharj urban-rural continuum depending on several criteria. The results revealed that there are five 
categories of spatial suitability including; "areas with very high spatial suitability" (66-86\%) constituting an area of $511.45 \mathrm{~km}^{2}$ representing $18.8 \%$ of the total area of the continuum, "areas with high spatial suitability" (62-66\%) constituting an area of $731.27 \mathrm{~km}^{2}(26.88 \%)$, "areas with moderate spatial suitability" (57-62\%) constituting an area of $820.5 \mathrm{~km}^{2}(30.16 \%)$, "areas with low spatial suitability" $(51-57 \%)$ constituting an area of $491.59 \mathrm{~km}^{2}(18.07 \%)$, and "areas with very low spatial suitability" (32-51\%) constituting an area of $165.68 \mathrm{~km}^{2}(6.09 \%)$.

The study also determined high priority projects that support the sustainable development plan for the area through constructing local urban development centers and targeted rural complexes along Ar Riyad-Al Kharj rural-urban continuum corridor according to the former strategic national urban plan and the regional urban planning plan of Ar Riyadh governorate. The study also supports the recommendations of forbidding of establishing of other activities in order not to allow any expansion of the urban masses of both Ar Riydh and Al kharj and ensuring the study area to be an urban separator between these cities, avoiding social and environmental problems that may arise from the urban conjugation. This also will protect the current industrial facilities as much as possible and decrease the cost of moving these facilities away from the area and the related costs of disowning the lands of these industrial facilities, and the job opportunities that should be provided to population to limit the immigration to the civilized cities (Ar Riyadh and Al kharj).

Author Contributions: A.A.E.K. designed the study; developed the research idea and planned the research activities; carried out the research, including collecting the input data and preparing the manuscript; carried out a statistical analysis of the obtained results; replied to the reviewers' comments; wrote the manuscript; provided valuable comments in writing this paper; professionally edited the manuscript; and designed the methodology. I.I.A. carried out statistical and spatial analyses of monitoring the changes in land use; I.Y. and H.M.A. carried out statistical and spatial analyses of monitoring the changes in land use, visited the field of the study area, and analysed the natural parameters affecting land use. All authors have read and agreed to the published version of the manuscript.

Funding: This Research was funded by the Deanship of Scientific Research at Princess Nourah bint Abdulrahman Universtiy, through the Research Funding Program (Grant No\# FRP-1440-33).

Acknowledgments: The authors highly appreciate the great support from the Deanship of Scientific Research at Princess Nourah bint Abdulrahman University (Grant No\# FRP-1440-33).

Conflicts of Interest: The authors declare no conflict of interest.

\section{References}

1. UNDESA/PD. World Population Prospects: The 2012 Revision, Highlights and Advance Tables. Available online: https://esa.un.org/unpd/wpp/publications/Files/WPP2012_HIGHLIGHTS.pdf (accessed on 20 September 2019).

2. UNDESA/PD. World Urbanization Prospects: The 2014 Revision, Highlights; (ST/ESA/SER.A/352); United Nations: New York, NY, USA, 2014.

3. Cobbinah, B.; Erdiaw-Kwasie, O.; Amoateng, P. Rethinking sustainable development within the framework of poverty and urbanization in developing countries. Environ. Dev. 2015, 13, 18-32. [CrossRef]

4. UN-Habitat. Prosperity of Cities. In State of the World Cities 2012/2013, 1st ed.; UN-Habitat: Nairobi, Kenya, 2012; p. 152. Available online: https://sustainabledevelopment.un.org/content/documents/745habitat.pdf (accessed on 20 September 2019).

5. Hamin, M.; Gurran, N. Urban form and climate change: Balancing adaptation and mitigation in the USA and Australia. Habitat Int. 2009, 33, 238-245. [CrossRef]

6. Cobbinah, B.; Erdiaw-Kwasie, O.; Amoateng, P. Africa's urbanization: Implications for sustainable development. Cities 2015, 47, 62-72. [CrossRef]

7. Ravetz, J.; Christian, F.; Nielsen, S. The dynamics of peri-urbanization. In Peri-Urban Futures Scenarios and Models for Land Use Change in Europe; Nilsson, K., Pauleit, S., Bell, S., Aalbers, C., Nielsen, T.S., Eds.; Springer: Heidelberg, Germany; New York, NY, USA; Dordrecht, The Netherlands; London, UK, 2013; pp. $13-44$.

8. Mbiba, B.; Huchzermeyer, M. Contentious development: Peri-urban studies in sub-Saharan Africa. Prog. Dev. Stud. 2002, 2, 113-131. [CrossRef] 
9. Simon, D.; McGregor, D.; Nsiah-Gyabaah, K. The changing urban-rural interface of African cities: Definitional issues and an application to Kumasi, Ghana. Environ. Urban. 2004, 16, 235-248. [CrossRef]

10. Kombe, J. Land use dynamics in peri-urban areas and their implications on the urban growth and form: The case of Dar es Salaam, Tanzania. Habitat Int. 2005, 29, 113-135. [CrossRef]

11. Thuo, A.D.M. Community and Social Responses to Land Use Transformations in the Nairobi Rural-Urban Fringe, Kenya. Field Actions Sci. Rep. J. Field Actions Urban Agric. 2010. Available online: http://journals. openedition.org/factsreports/435 (accessed on 25 September 2019).

12. Tajbakhsh, M.; Memarian, H.; Shahrokhi, H. Analyzing and modeling urban sprawl and land use changes in a developing city using a CA-Markovian approach. Glob. J. Environ. Sci. Manag. 2016, 2, 397-410. [CrossRef]

13. Mandere, N.; Ness, B.; Anderberg, S. Peri-urban development, livelihood change and household income: A case study of peri-urban Nyahururu, Kenya. J. Agric. Ext. Rural Dev. 2010, 2, 73-83.

14. Acheampong, A.; Anokye, A. Understanding households' residential location choice in Kumasi's peri-urban settlements and the implications for sustainable urban growth. Res. Humanit. Soc. Sci. 2013, 3, 60-70.

15. Laquinta, L.; Drescher, W. Defining the peri-urban: Rural-urban linkages and institutional connections. Land Reform 2000, 6, 1-28.

16. Akrofi, O.; Whittal, J. Land for peri-urban infrastructure in customary areas: A case study of Kumasi, Ghana. In Proceedings of the FIG Working Week 2011 Bridging the Gap between Cultures, Marrakech, Morocco, 18-22 May 2011; pp. 1-16. [CrossRef]

17. Amoateng, P.; Cobbinah, B.; Owusu-Adade, K. Managing physical development in peri-urban areas of kumasi, Ghana: A case of Abuakwa. J. Urban Environ. Eng. 2013, 7, 96-109. [CrossRef]

18. McGregor, M.; Adam-Bradford, A.; Thompson, A.; Simon, D. Resource management and agriculture in the peri-urban interface of Kumasi, Ghana: Problems and prospects. Singap. J. Trop. Geogr. 2011, 32, 382-398. [CrossRef]

19. Kazil, M.; Ali, M. Evaluation of land suitability for urban land use planning: Case study of Dhaka city. Trans. GIS 2015, 20, 20-37. [CrossRef]

20. De la Rosa, D.; Van Diepen, A. Land Use, Land Cover and Soil Sciences. Qualitative and Quantitative Land Evaluations (Agro-Ecological Land Evaluation); Encyclopedia of Life Support Cultural Organization: Oxford, UK, 2002; Volume 2, pp. 1-8.

21. Steiner, F.; McSherry, L.; Cohen, J. Land suitability analysis for the Upper Gila River Watershed. Landsc. Urban Plan. 2000, 50, 199-214. [CrossRef]

22. Collin, L.; Melloul, J. Combined land-use and environmental factors for sustainable groundwater management. Urban Water 2001, 3, 229-237. [CrossRef]

23. Shearer, S.; Xiang, N. Representing multiple voices in landscape planning: A land suitability evaluation study for a park land-banking program in Concord, North Carolina, USA. Landsc. Urban Plan. 2009, 93, 111-122. [CrossRef]

24. Bojórquez-Tapia, A.; Diaz-Mondragón, S.; Ezcurra, E. GIS-based approach for participatory decision making and land suitability evaluation. Int. J. Geogr. Inf. Sci. 2001, 15, 129-151. [CrossRef]

25. Malczewski, J. Ordered weighted averaging with fuzzy quantifiers: GIS-based multicriteria evaluation for land-use suitability analysis. Int. J. Appl. Earth Obs. 2006, 8, 270-277. [CrossRef]

26. Chen, H.; Liu, G.; Yang, Y.; Ye, X.; Shi, Z. Comprehensive Evaluation of Tobacco Ecological Suitability of Henan Province Based on GIS. Agric. Sci. China 2010, 9, 583-592. [CrossRef]

27. Chen, Y.; Yu, J.; Khan, S. Spatial sensitivity analysis of multi-criteria weights in GIS-based land suitability evaluation. Environ. Modell. Softw. 2010, 25, 1582-1591. [CrossRef]

28. Gallant, L.; Euliss, H.; Browning, Z. Mapping Large-Area Landscape Suitability for Honey Bees to Assess the Influence of Land-Use Change on Sustainability of National Pollination Services. PLoS ONE 2014, 9, e99268. [CrossRef] [PubMed]

29. McHarg, L. Design with Nature; Natural History Press: Garden City, NY, USA, 1969.

30. Bauer, W. The use of soils data in regional planning. Geoderma 1973, 10, 1-26. [CrossRef]

31. Fabos, Y.; Greene, M.; Joyner, A. The Metland Landscape Planning Process: Composite Landscape Evaluation, Alternative Plan Formulation, and Plan Evaluation; Massachusetts Agricultural Experiment Station; University of Massachusetts: Amherst, MA, USA, 1978. 
32. Wandahwa, P.; Van Ranst, E. Qualitative land suitability evaluation for pyrethrum cultivation in west Kenya based upon computer-captured expert knowledge and GIS. Agric. Ecosyst. Environ. 1996, 56, 187-202. [CrossRef]

33. Ahamed, N.; Rao, G.; Murthy, R. GIS-based fuzzy membership model for crop-land suitability analysis. Agric. Syst. 2000, 63, 75-95. [CrossRef]

34. Mendas, A.; Delali, A. Integration of MultiCriteria Decision Analysis in GIS to develop land suitability for agriculture: Application to durum wheat cultivation in the region of Mleta in Algeria. Comput. Electron. Agric. 2012, 83, 117-126. [CrossRef]

35. Reshmidevi, V.; Eldho, I.; Jana, A. GIS-integrated fuzzy rule-based inference system for land suitability evaluation in agricultural watersheds. Agric. Syst. 2009, 101, 101-109. [CrossRef]

36. Wang, D.; Li, C.; Song, X.; Wang, J.; Yang, X.; Huang, W.; Wang, J.; Zhou, J. Evaluation of Land Suitability Potentials for Selecting Winter Wheat Cultivation Areas in Beijing, China, Using RS and GIS. Agric. Sci. China 2011, 10, 1419-1430. [CrossRef]

37. Yu, J.; Chen, Y.; Wu, J.; Khane, S. Cellular automata-based spatial multi-criteria land suitability simulation for irrigated agriculture. Int. J. Geogr. Inf. Sci. 2011, 25, 131-148. [CrossRef]

38. Liu, Y.; Jiao, L.; Liu, Y.; He, J. A self-adapting fuzzy inference system for the evaluation of agricultural land. Environ. Modell. Softw. 2013, 40, 226-234. [CrossRef]

39. Yalew, G.; Van Griensven, A.; Van der Zaag, P. AgriSuit: A web-based GIS-MCDA framework for agricultural land suitability evaluation. Comput. Electron. Agric. 2016, 128, 1-8. [CrossRef]

40. Kong, C.; Lan, H.; Yang, G.; Xu, K. Geo-environmental suitability evaluation for agricultural land in the rural-urban fringe using BPNN and GIS: A case study of Hangzhou. Environ. Earth Sci. 2016, 75, 1136. [CrossRef]

41. Uy, D.; Nakagoshi, N. Application of land suitability analysis and landscape ecology to urban greenspace planning in Hanoi, Vietnam. Urban For. Urban Green. 2008, 7, 25-40. [CrossRef]

42. Pourebrahim, S.; Hadipour, M.; Mokhtar, B.; Mohamed, H. Analytic network process for criteria selection in sustainable coastal land use planning. Ocean Coast. Manag. 2010, 53, 544-551. [CrossRef]

43. Aragonés-Beltrán, P.; Pastor-Ferrando, P.; García-García, F.; Pascual-Agulló, A. An Analytic Network Process approach for siting a municipal solid waste plant in the Metropolitan Area of Valencia (Spain). J. Environ. Manag. 2010, 91, 1071-1086. [CrossRef]

44. Baiocchi, V.; Lelo, K.; Polettini, A.; Pomi, R. Land suitability for waste disposal in metropolitan areas. Waste Manag. Res. 2014, 32, 707-716. [CrossRef]

45. Chang, N.; Parvathinathan, G.; Breeden, B. Combining GIS with fuzzy multicriteria decision-making for landfill siting in a fast-growing urban region. J. Environ. Manag. 2008, 87, 139-153. [CrossRef]

46. Marull, J.; Mallarach, M. A GIS methodology for assessing and predicting landscape and ecological connectivity: Applications to the metropolitan area of Barcelona (Catalonia Spain). Landsc. Urban Plan. 2005, 71, 243-262. [CrossRef]

47. Maher, A.; Sbrina, A.; Mohammed, F.; Zulfa, H. Land suitability analysis of urban growth in Seremban Malaysia, using GIS based Analytical Hierarchy Process. Procedia Eng. 2017, 198, 1128-1136. [CrossRef]

48. Wang, S.; Liu, C.; Zhang, H. Suitability evaluation for land reclamation in mining area: A case study of Gaoqiao bauxite mine. Trans. Nonferrous Met. Soc. China 2011, 21, 506-515. [CrossRef]

49. Sadeeka, L.; Lalit, K.; Janaki, S. Assessment of Potential Land Suitability for Tea (Camellia sinensis (L.) O. Kuntze) in Sri Lanka Using a GIS-Based Multi-Criteria Approach. Agriculture 2019, 9, 148. [CrossRef]

50. Ronja, H.; Tung, G.; Martin, K.; Daniel, W.; Chau, T. Multi-Criteria Decision Analysis for the Land Evaluation of Potential Agricultural Land Use Types in a Hilly Area of Central Vietnam. Land 2019, 8, 90. [CrossRef]

51. Xu, K.; Kong, C.; Li, J.; Zhang, L.; Wu, C. Suitability evaluation of urban construction land based on geo-environmental factors of Hangzhou, China. Comput. Geosci. 2011, 37, 992-1002. [CrossRef]

52. Cerreta, M.; Toro, D. Urbanization suitability maps: A dynamic spatial decision support system for sustainable land use. Earth Syst. Dyn. 2012, 3, 157-171. [CrossRef]

53. Malmir, M.; Zarkesh, K.; Monavari, M.; Jozi, A.; Sharifi, E. Analysis of land suitability for urban development in Ahwaz County in southwestern Iran using fuzzy logic and analytic network process (ANP). Environ. Monit. Assess. 2016, 188, 447. [CrossRef] 
54. Qingsheng, L.; Jinliang, H.; Cui, W.; Heshan, L.; Jiwei, Z.; Jinlong, J.; Bingkun, W. Land Development Suitability Evaluation of Pingtan Island Based on Scenario Analysis and Landscape Ecological Quality Evaluation. Sustainability 2017, 9, 1292. [CrossRef]

55. Joerin, F.; Thériault, M.; Musy, A. Using GIS and outranking multicriteria analysis for land-use suitability assessment. Int. J. Geogr. Inf. Sci. 2001, 15, 153-174. [CrossRef]

56. Ananstasia, T.; Charikleia, K.; Konstantions, M.; Konstantions, M.; Chrysanthi, K. Land use planning decisions using multi-criteria analysis: The case of the master plan for the western part of the coastal zone of Thessaloniki, Greece. Int. J. Real Estate Land Plan. 2018, 1, 1-19.

57. Rosli, A.; Reba, M.; Room, M. Sustainable Urban Forestry Potential Based Quantitative And Qualitative Measurement Using Geospatial Technique. IOP Conf. Ser. Earth Environ. Sci. 2014, 18, 1-7. [CrossRef]

58. Park, S.; Jeon, S.; Kim, S.; Choi, C. Prediction and comparison of urban growth by land suitability index mapping using GIS and RS in South Korea. Landsc. Urban Plan. 2011, 99, 104-114. [CrossRef]

59. Bagheri, M.; Sulaiman, A.; Vaghefi, N. Application of geographic information system technique and analytical hierarchy process model for land-use suitability analysis on coastal area. J. Coast. Conserv. 2013, 17, 1-10. [CrossRef]

60. Duc, T. Using GIS and AHP technique for land-use suitability analysis. In Proceedings of the International Symposium on Geoinformatics for Spatial Infrastructure Development in Earth and Allied Sciences, Hanoi, Vietnam, 16-18 September 2004.

61. Montgomery, B.; Dragi'cevi'c, S.; Dujmovi'c, J.; Schmidt, M. A GIS-based Logic Scoring of Preference method for evaluation of land capability and suitability for agriculture. Comput. Electron. Agric. 2016, 124, 340-353. [CrossRef]

62. Grima, N.; Singh, S.J.; Smetschka, B. Improving payments for ecosystem services (PES) outcomes through the use of Multi-Criteria Evaluation (MCE) and the software OPTamos. Ecosyst. Serv. 2018, 29, 47-55. [CrossRef]

63. Cover, J. Integrating multi-criteria evaluation with of the geographical information systems. Int. J. Geogr. Inf. Syst. 1991, 5, 321-339. [CrossRef]

64. Van den Bossche, J.; De Baets, B.; Verwaeren, J.; Botteldooren, D.; Theunis, J. Development and evaluation of land use regression models for black carbon based on bicycle and pedestrian measurements in the urban environment. Environ. Model. Softw. 2018, 99, 58-69. [CrossRef]

65. Lee, M.; Yeh, C. Applying remote sensing techniques to monitor shifting wetland vegetation: A case study of Danshui River estuary mangrove communities, Taiwan. Ecol. Eng. 2009, 35, 487-496. [CrossRef]

66. Pan, G.; Pan, J. Research in cropland suitability analysis based on GIS. Inter. Confer. Comput. Comput. Technol. Agric. 2012, 365, 314-325. [CrossRef]

67. Hasan, Z.; Mohsen, A.; Philip, K.; Mohammadreza, K.; Himan, S.; Anuer, A.; Mohamed, N.; Saro, L. GIS Multi-Criteria Analysis by Ordered Weighted Averaging (OWA): Toward an Integrated Citrus Management Strategy. Sustainability 2019, 11, 1009. [CrossRef]

68. Araya, K.; Mltiku, H.; Glrmay, G.; Muktar, M. GIS-based multi-criteria model for land suitability evaluation of rainfed teff crop production in degraded semi-arid highlands of Northern Ethiopia. Modeling Earth Syst. Environ. 2018, 4, 1467-1486. [CrossRef]

69. Merlos, F.; Monzon, P.; Mercau, L.; Taboada, M.; Andrade, H.; Hall, J.; Jobbagy, E.; Cassman, G.; Grassini, P. Potential for Crop Production Increase in Argentina Through Closure of Existing Yield Gaps. Field Crop. Res. 2015, 184, 145-154. [CrossRef]

70. Baja, S.; Nesati, R.; Arif, S. Land use and land suitability assessment within the context of spatial planning regulation. IOP Conf. Ser. Earth Environ. Sci. 2018, 157, 1-7. [CrossRef]

71. Huiping, H.; Qiangzi, L.; Yuan, Z. Urban Residential Land Suitability Analysis Combining Remote Sensing and Social Sensing Data: A Case Study in Beijing, China. Sustainability 2019, 11, 2255. [CrossRef]

72. Chuvieco, E. Integration of linear programming and GIS for land-use modelling. Int. J. Geogr. Information Sci. 1993, 7, 71-83. [CrossRef]

73. Abudeif, A.; Abdel Moneim, A.; Farrag, A. Multi criteria decision analysis based on analytic hierarchy process in GIS environment for siting nuclear power plant in Egypt. Ann. Nucl. Energy 2015, 75, 682-692. [CrossRef]

74. López, T.; Yarnal, B. Putting adaptive capacity into the context of people's lives: A case study of two flood-prone communities in Puerto Rico. Nat. Hazards 2010, 52, 277-297. [CrossRef] 
75. Akıncı, H.; Ayse, Y.; Bulent, T. Agricultural land use suitability analysis using GIS and AHP technique. Comput. Electron. Agric. 2013, 97, 71-82. [CrossRef]

76. ESRI, Arc GIS, Version 10X Help. Available online: https://desktop.arcgis.com/en/arcmap/latest/extensions/ network-analyst/location-allocation.htm (accessed on 24 October 2019).

77. Ghanavati, E. Flood Risk Zonation for Karaj City Using Fuzzy Logic. Geogr. Environ. Hazards 2014, 8, $23-25$.

78. Ashraf, A.; Ahmed, F.; Ahmed, M.; Biswajeet, P. Flood Hazard Assessment of the Urban Area of Tabuk City, Kingdom of Saudi Arabia by Integrating Spatial-Based Hydrologic and Hydrodynamic Modeling. Sensors 2019, 19, 1024. [CrossRef]

79. Ashraf, A.; Ahmed, F. Flood Risk Assessment of the Wadi Nu'man Basin, Mecca, Saudi Arabia (During the Period, 1988-2019) Based on the Integration of Geomatics and Hydraulic Modeling: A Case Study. Water 2019, 11, 1887. [CrossRef]

80. Alexander, K.; Benjamin, M.; Grephas, P. Urban landuse suitability assessment using geoinformation techniques for Kisumu municipality in Kenya. Int. J. Res. Rev. Appl. Sci. 2012, 13, 522-530.

81. Houghton, A.; Hackler, L.; Lawrence, T. The U.S. Carbon Budget: Contributions from Land-Use Change. Science 1999, 285, 574-578. [CrossRef] [PubMed]

82. Bhagat, B. Urbanisation and access to basic amenities in India. Urban India 2011, 31, 1-13.

(C) 2020 by the authors. Licensee MDPI, Basel, Switzerland. This article is an open access article distributed under the terms and conditions of the Creative Commons Attribution (CC BY) license (http://creativecommons.org/licenses/by/4.0/). 